IFN Working Paper No. 857, 2011

\title{
The Swedish Corporate Control Model: Convergence, Persistence or Decline?
}

Magnus Henrekson and Ulf Jakobsson 


\title{
The Swedish Corporate Control Model: Convergence, Persistence or Decline?*
}

\author{
Magnus Henrekson ${ }^{\ddagger}$ and Ulf Jakobsson
}

\begin{abstract}
August 19, 2011
Abstract: This paper explores the effects of deregulation and globalization on the dominant mode of corporate governance in Swedish public firms. The effects are multidimensional-the direction of change in corporate governance cannot be determined by simply examining whether a convergence towards the Anglo-American model is occurring. Dispersed ownership with management control has not proven to be a viable model of corporate governance for Swedish listed companies. Instead, the control models with the most rapid growth in the most recent decades are found outside the stock market, notably private equity and foreign ownership. After a major revival of the Swedish stock market its importance for the Swedish economy is again in decline. Instead of adjustments in pertinent institutions and practices to ensure effectiveness of the corporate governance of Swedish public firms under these new conditions, a great deal of endogenous adjustment of the ownership structure has taken place. A major lesson from this study is that unless institutional reform renders management entrenchment and/or board independence possible, convergence to the Anglo-American model cannot take place.
\end{abstract}

Keywords: Corporate control, Corporate governance, Corporatism, Entrepreneurship, Ownership policy, Ownership structure, Swedish model.

JEL Codes: M13, N24, 038, P16.

\author{
${ }^{\ddagger}$ Corresponding author \\ Research Institute of Industrial Economics (IFN) \\ P.O. Box 55665 \\ SE-102 15 Stockholm \\ Phone: +46-8-665 4500 \\ Fax: +46-8-665 4599 \\ e-mail: magnus.henrekson@ifn.se \\ e-mail: ulf.jakobsson@ifn.se
}

\footnotetext{
*We are grateful for excellent research assistance from Aron Berg, and useful comments and suggestions from Sophie Nachemson-Ekwall, Mats Isaksson, Jesper Roine, Tomas Nicolin, Per-Olof Bjuggren, Ragnar Boman, Jennifer Hill, Helena Svaleryd, Sven-Ivan Sundqvist, Daniel Waldenström, Steen Thomsen and Linda Nyberg. Financial support from the Jan Wallander and Tom Hedelius Research Foundation, the Nasdaq OMX Nordic Foundation and from Catarina och Sven Hagströmers Stiftelse is gratefully acknowledged.
} 


\section{Executive summary}

Research Question/Issue: In the finance literature theoretical arguments have largely predicted a world-wide convergence towards the Anglo-American model of corporate control. Still, there are few signs that this convergence is underway. This paper explores the reasons for the persistence of the blockholder model by an in-depth examination of a single country-Sweden-where blockholding always has been strong and where it still predominates among public firms. In spite of the fact that we explore the effects of deregulation, globalization and regulatory reform on corporate governance in a single country, a further aim is to shed some light on the wider issue of the world-wide persistence of the blockholder model.

Research Findings/Insights: We find that globalization has undermined the traditional model of corporate control in Sweden. However, there is no sign of expansion of the Anglo-American model of corporate control. A prerequisite for a well-functioning model of dispersed ownership and management control is a certain degree of autonomy/entrenchment for management relative to owners. In Sweden this option is precluded by the corporate law and prevailing social norms. As a result, the Anglo-American model is not viable and blockholder control still predominates among public firms. However, the importance of the stock exchange is declining and there is strong growth of control models outside the stock exchange, notably private equity and foreign ownership.

Theoretical/Academic Implications: In the theoretical argumentation for the inevitability of the Anglo-American model in a mature economy too little attention has been given to the necessary conditions for the viability of management control in the case of dispersed ownership. A rigorous treatment of this question is needed if we want to formulate a relevant theory for the nature of endogenous adjustment of control models in response to globalization.

Practitioner/Policy Implications:. Reforms in corporate finance implemented in the European Union are greatly inspired by the U.K. system. In traditional blockholder governance systems such reforms undermine the basis for blockholder control. If there are strong cultural and/or legal impediments to the emergence of firms with dispersed ownership and management control, institutional convergence could result in an erosion of national stock markets in Europe. The study also provides support for the argument that the efficiency of a particular corporate governance model hinges on the complementarity of several constitutive elements, and therefore an isolated change in a certain element leads to inconsistencies, making the model less efficient. 


\section{Introduction}

There are two basic models of corporate governance of public firms (in developed economies): (i) dispersed ownership and management control, and (i) concentrated ownersh ${ }^{i} p$ and private blockholder control. The first model predominates in the Anglo-American world, where common law judicial systems largely govern. The second model, which exists in several varieties, dominates in virtually all other countries (Morck 2005; Gourevitch and Shinn 2005).

This dichotomy developed early in the first decades of the 20th century. As firms and stock markets grew, and corporate law changed in response, most of the blockholdings in large, Anglo-American corporations were discontinued, particularly in the United States (Morck 2005). Berle and Means (1932) "codified" this new state of affairs when describing managerial control as the inevitable consequence of dispersed ownership. Dispersed ownership in turn grew from the combined effects of the sheer size of the stock market, wealthy investors' preference for a diversified asset portfolio, government antitrust action, large market capitalization of the big firms, and the illusion held by several leading families that they could retain control despite having sold their control block (Becht and DeLong 2005).

The Berle-Means view of the modern public corporation dominated the (mostly Anglo-American) research literature on corporate governance for decades. When La Porta et al. (1999) documented that concentrated ownership and blockholding was indeed the prevailing corporate governance model in non-Anglo-American countries, it was seen as something of a scientific breakthrough.

In recent decades the framework conditions for large and medium-sized corporations have changed dramatically as a result of the rapid growth of institutional ownership and the globalization of capital markets. Theoretically, these forces could transform both corporate governance models. Drucker (1976) argued that the growth of pension funds would in practice socialize the U.S. corporate sector, with far-reaching consequences for the governance of U.S. corporations. Similarly, the increased ownership of American firms by Japanese and, more recently, Chinese investors and Sovereign Wealth Funds has spurred alarmist reactions across the U.S. Yet the Anglo-American corporate governance model seems to have accommodated these changes so far.

As for the blockholder model, theoretical arguments anticipate that structural changes will likely require its modification. Theoretical arguments most commonly predict a world-wide convergence towards the Anglo-American model. Hansmann and Kraakman (2004) extend some of the scholarly world's most forceful arguments in favor of convergence.

Arguments against convergence have also been raised, many of them of a political nature. For example, Roe $(2003,2004)$ has maintained that dispersed ownership is not a viable control model in economies where social-democratic ideologies and concomitant institutions empower employees relative to owners or management.

Still, few signs have emerged as yet to indicate that a general convergence towards the AngloAmerican model is underway. Why does the blockholder model persist in its varieties despite it being 
judged as inferior to the Anglo-American model by many finance scholars and regarded with suspicion by international institutional investors? ${ }^{1}$

We will explore this question by studying how corporate governance has developed over the last three decades in one country-Sweden-a place where blockholding by controlling owners has always been predominant. The Swedish case is of general interest for a couple of reasons. First, this aspect of the Swedish social model is likely to be of interest also outside the community of scholars studying comparative corporate governance. Second, Swedish economic performance seems to have benefitted from globalization; the GDP per capita growth rate has been on average 0.9 percentage points greater than for the OECD average in the 1994-2010 period, resulting in an increase in PPPadjusted GDP per capita of roughly 15 percentage points relative to the OECD average since 1993.

Beginning after the Second World War, corporate control became increasingly concentrated, at least until the early 1990s. Voting rights have been differentiated from cash-flow rights by intense use of dual-class shares and pyramiding. By the early 1990s, the two dominant ownership groups in Sweden had used these instruments to control 50 percent of the market cap of the Stockholm Stock Exchange (SSE) based on a mere two percent of the dividend rights.

Sweden certainly belongs to a large family of countries where control by blockholding is the dominant corporate governance model. Unique to the Swedish model, though, is that the wealth on which the controlling ownership is based had become extremely thin by the 1990s, probably thinner than in any other country (Agnblad et al. 2001). Therefore, among the countries characterized by blockholder control of listed firms, the Swedish control model could be expected to be more vulnerable both to the forces of globalization and the growth of institutional ownership. As a result, an exploration into why the blockholder model persists in Sweden applies more generally.

Moreover, Sweden is of special interest with respect to the relationship between corporate governance and the political influence of organized labor. According to Roe (2003), the Swedish labor movement enjoys stronger influence than in any other country. Henrekson and Jakobsson (2001) have also documented how the governance model evolved in strong connection with the politics and the ideology of the predominant Social Democrats. An interesting question is whether the apparent persistence of the model can be interpreted as a vindication of Roe's hypothesis.

The question of whether Swedish corporate governance is converging has been analyzed by Högfeldt (2005), Carlsson (2007) and Henrekson and Jakobsson (2005). The first two authors both find that the traditional Swedish model of "old capital" still dominates among listed Swedish firms. Högfeldt $(2005$, p. 538) concludes that "[d]espite the very significant increase of institutional capital and foreign capital, corporate ownership is as entrenched as ever in Sweden since the largest firms are

\footnotetext{
${ }^{1}$ Within the framework of financial economics it is difficult to plausibly explain how this model can be sustained despite the forces of globalization and increased institutional ownership. Lack of convergence towards the Anglo-American model is seen as resulting from inefficient "entrenchment". In the "varieties of capitalism" literature, where the importance of the complementarity between the ownership structure and the type of economic activity in a country is stressed, a lack of convergence is not necessarily seen as inefficient. The response to globalization is instead explained by the nature of this complementarity (Carlin 2010). Bebchuk and Roe (2004) provide a long list of arguments that indicate stickiness in existing rules even when globalization pushes towards convergence. Schmidt and Spindler (2002) stress the importance of the complementarity of various elements in corporate governance models. As a result, changes in a certain element in the direction of the Anglo-Saxon model lead to inconsistencies, making the model less efficient.
} 
still controlled by an old financial nobility of the third to fifth generation and by banks, but to a much lesser extent by institutions that provide the majority of the capital." This conclusion was based on data ending in 2000, and it is quite clear that it no longer holds true, and, as we will show, it is doubtful that it was true even then. ${ }^{2}$

We argue that the effects of deregulation and globalization on the Swedish corporate sector are multidimensional; the direction of corporate governance cannot be determined by simply examining whether the governance of public firms is converging to the Anglo-American model. Instead, our findings can be summarized in the following five points:

1. The traditional model of Swedish ownership based on "old capital" reached its zenith on the SSE in the early 1990s and has since been in decline.

2. Extensive deregulation and more pro-market economic policy combined with the dramatic increase of stock market valuations to create a number of new fortunes that were large enough to constitute the capital base for controlling ownership in listed companies.

3. Dispersed ownership with management control has not proven to be a viable model of corporate governance for Swedish listed companies; among listed firms blockholding is still (in 2011) the dominant form of corporate control.

4. The control models with the most rapid growth in recent decades are found outside the stock market.

5. The Swedish stock market's importance for the Swedish economy is again in decline after a major revival.

Two findings in our study stand out as being of greater general importance. First, unless reform in pertinent institutions renders management entrenchment and/or board independence possible, convergence to the Anglo-American model cannot take place. Second, if management entrenchment/board independence is not possible, the combined effect of globalization and the institutionalization of savings is likely to lead to a declining aggregate role for public firms; other forms of ownership, notably private equity and foreign ownership, gain in importance. The credence of the latter conclusion is strengthened by the fact that recent reforms in the U.S. have strengthened shareholders' rights in public firms (Hill, 2010), which is one likely reason why the aggregate importance of public firms is declining there as well. Before we discuss our findings, we will briefly review the main arguments in the debate on convergence of corporate governance.

\section{Why Should There Be Convergence towards the Anglo-American Model?}

The basic argument for convergence towards the Anglo-American model can be traced to Berle and Means (1932). In their classic book they argued that dispersed ownership with managerial control was the inevitable governance model in public companies in mature economies. In a public company, they maintained, single shareholders have no incentive to take on the burden of control through blockholding. Blockholding precludes a rational portfolio diversification and has an inherent tendency of locking in investments, which reduces portfolio liquidity. If minority protection is effective, no

\footnotetext{
${ }^{2}$ Collin (1995) is another observer who asserts that the ownership groups based on "old" capital maintained their relative position in the early 1990s.
} 
rewards can be reaped from exercising control in a firm. If one owner assumes the role of controlling the company, the other shareholders can free-ride on this effort. Since no rational shareholder would be willing to act as controlling blockholder, dispersed ownership with managerial control emerges by default.

A corollary to this argument is that blockholding only emerges when minority protection is weak (because of the corporate law or corporate culture), so that controlling blockholders can extract private benefits from the firm. In this case, the only stable governance model is blockholder control (Gilson 2006).

Plenty of empirical evidence suggests that blockholders actually do engage in such extraction of benefits. ${ }^{3}$ Control by blockholding mostly requires a separation of dividend rights and voting rights, which is most commonly achieved through pyramiding and/or dual-class shares. Sweden is one of the countries where dual-class shares has been most common (Cronqvist and Nilsson 2003).

Together with an increase in shares held by institutional investors, the globalization of stock markets has augmented institutional investors' role as a source of capital for public firms. Their views on corporate governance seem to be dominated by the Anglo-American model of corporate control. As a result, markets and firms that do not comply with this model tend to get a lower valuation. Based on a survey of 200 listed companies in 1985-2000, Holmén and Nivorozhkin (2007) find that firms with differential voting rights receive a lower valuation as measured by Tobin's $q$. This is also found by Bjuggren et al. (2007) in a similar study, and by Barontino and Caprio (2005) for other European stock markets. In the latter study of 675 listed companies in Continental Europe and Scandinavia it is found that the valuation is higher in firms controlled by a family, unless control is based on a separation of control rights from cash-flow rights. This is also what Holmén and Nivorozhkin (2007) find for Sweden. This result is largely consistent with the theoretical literature (Burkart and Lee 2008).

Internationalization of capital markets pushes towards convergence in at least two ways. First, governments in countries with weak investor protection may adapt corporate law towards the AngloAmerican ideal in order to attract investment capital from abroad (Hansmann and Kraakman 2004). Second, firms themselves will adjust to the preferences of international institutional investors by reducing the use of dual-class shares. ${ }^{4}$ Table 1 demonstrates this effect in Swedish firms, yet the evidence is by no means unequivocal. Immediately after the deregulation process began, the use of dual-class shares increased; after 1992, however, the share declined significantly. Controlling owners initially tried to defend their control position in the new environment by escalating their use of dualclass shares. When the stock market settled down to a new equilibrium after the big slump in 199293, the lower valuation of companies with dual-class shares became more burdensome and firms adjusted accordingly.

\footnotetext{
${ }^{3}$ See, e.g., Morck et al. (2005).

${ }^{4}$ Holmén (2011) provides evidence that the discount on dual-class firms first arose in connection with the lifted ban on foreing ownership on the SSE in 1993.
} 
Table 1 The Percentage of Listed Companies on the Stockholm Stock Exchange with Dual-Class Shares, Selected Years 1950-2010.

\begin{tabular}{lrrrrr}
\hline Year & Share & No. of firms & Year & Share & No. of firms \\
\hline 1950 & 18 & 91 & 1986 & 74 & 217 \\
1963 & 29 & 112 & 1992 & 87 & 202 \\
1968 & 32 & 146 & 1998 & 63 & 304 \\
1972 & 36 & 134 & 2006 & 46 & 295 \\
1977 & 44 & 130 & 2008 & 46 & 299 \\
1981 & 54 & 128 & 2010 & 49 & 255 \\
\hline
\end{tabular}

Note: When dual-class shares are used, so-called A-shares normally have a voting power ten times higher than the B-shares. Prior to 2003, this ratio reached as high as 1000:1, notably in Ericsson, Electrolux and SKF. The Swedish Securities Dealers' Association managed an alternative list-Fondhandlarlistan - with less stringent listing requirements. In the 1950s, 60s and 70s this stock exchange contained 30 to 40 companies (SOU 1968:59, p. 47; Jansson 2008, p. 149-153). Many firms first went public by being quoted on that list, among them H\&M, the company with the highest market cap on the SSE in 2010. This alternate list was abolished in 1981 when the SSE was granted a government monopoly. Firms listed on the Nordic Growth Market (NGM) are included.

Source: Ulf Persson (NasdaqOMX), Högfeldt (2005, p. 564), Bergström and Rydqvist (1990), Isaksson and Skog (1994), Agnblad et al. (2001), Fristedt and Sundqvist (2009) and SIS Ägarservice.

Thus far, the arguments for convergence have skated on quite a general level, but more specific arguments beckon as well. Giannetti and Simonov (2006) and Denis and McConnell (2003) have maintained that the globalization of asset markets tends to be unfavorable for blockholders with a wide gap between control rights and cash-flow rights. When the playing field levels across investor categories and sources of finance, incentives for low dividends and financing with retained earnings are weakened. Market values are affected, and it becomes more attractive to finance the expansion of firms with rights issues. This puts the blockholding owners in a quandary. They either have to refrain from potential expansion and thereby eschew business opportunities, or undertake the expansion by rights issues, thereby diluting their control. Both choices reduce blockholding's role as a corporate governance mechanism.

Swedish CEIFs present a special case of the problems blockholders face when financing an expansion of the companies in their sphere. As shown in Figure 1, shares of CEIFs trade at a significant discount relative to the net value of their assets. The reasons behind this markdown are hotly debated. Since the rights in the portfolio usually are used for blockholding purposes, one explanation is that the discount simply is a reflection of the negative economies involved in blockholding that were just described. Holmén and Högfeldt (2005a) give, however, a more sophisticated but not necessarily exclusive explanation. They assert that, in order to avoid taxation, CEIFs have to transfer all dividends to their owners. (Beginning in 2003, such taxation can be avoided as long as the CEIF controls more than 10 percent of the vote in a firm.) That gives an incentive for the CEIFs to favor low dividends in the companies they control, resulting in excessive equity financing and overinvestment in these companies. On the margin, companies controlled by CEIFs tend to make unprofitable investment which leads to a discount on the CEIF. At any rate, a discount implies that there is a negative 
valuation of the management services provided by the CEIF, since the portfolio itself has a higher value without these services. ${ }^{5}$

Figure 1 Discount on the Share Price of Investor AB (1930-2010) and Industrivärden (1993-2010) Relative to the Net Asset Value (\%).

Note: Although the figure only displays the evolution of the discount for Investor and Industrivärden, it also applies to other investment companies, such as Lundbergs, Kinnevik, Latour and Custos. Neither is the discount a recent phenomenon. The average discount over longer time periods has been roughly 20 percent (Högfeldt 2005; Karlsson and Myrberg 1985).

Source: Lindgren (1994b) and Investor AB for Investor, and Swedbank for Industrivärden.

Whatever the explanation, as long as the CEIFs - normally controlled by a family or a family foundation at the top of the pyramid using dual-class shares-trade at a discount, they cannot issue new equity. Given that the overall stock market is growing, they lose the possibility to expand their resources in tandem with the growth of the aggregate market. Buying new control blocks for the proceeds have also become more difficult after the introduction of the mandatory bid rule in $1999 .^{6}$

Theoretically, a strong connection exists between control through blockholding and weak minority protection. In Sweden, however, minority protection is relatively strong in international comparison, and there is no evidence of undue exploitation by the majority (Holmén and Knopf 2004). Gilson (2006), for example, argues that strong non-pecuniary incentives for blockholding must exist in an economy with separation of ownership and control and strong minority protection. An obvious testament to this effect is the esteem that blockholding families continue to enjoy in society. Still, it remains unanswered how sustainable this incentive really is in an environment without pecuniary incentives for blockholding. There is reason to believe that the continued globalization and concomitant increase in competition with more efficiently organized companies raises the opportunity cost of the non-pecuniary benefits of maintaining control, which will likely erode the cultural assessment of the value of control.

We conclude that the theoretical arguments touting the convergence of the Swedish model of ownership and control towards the Anglo-American model are forceful. The next section will describe how the traditional Swedish model based on "old capital" has actually begun its decline. On the other hand, we will see that control by blockholding still enjoys complete dominance on the SSE.

\footnotetext{
${ }^{5}$ It is not quite clear to us why CEIFs themselves, and not only the companies they control, should trade at a discount. A partial explanation could be the net present value of the cost of operating the CEIF. This alone can create a considerable discount. Assuming that the operating costs of the CEIF amounts to 0.5 percent of net assets, and that the expected real rate of return on these assets is 5 percent p.a., this effect would give rise to a 10 percent discount. Still, it is likely that part of the discount emanates from the fact that the traditional CEIFs are not perceived as credible maximizers of the return on their blockholdings. Evidence speaking in favor of this hypothesis is the fact that the discount on the CEIF Ratos gradually vanished when their announced change of strategy from being a long-term blockholder to becoming a listed private equity firm was deemed credible. Shleifer (2000, ch. 3) gives another reason for expecting CEIFs to trade at a discount (which they also do the in the U.S. with few exceptions).

${ }^{6}$ Holmén and Nivorozhkin (2008) show that the mandatory bid rule (currently at $30 \%$ of the votes) entailed a large decrease in the premium paid for $A$ shares with more voting rights.
} 


\section{The Rise and Decline of the Traditional Swedish Model}

In Sweden, corporate control became highly concentrated as early as the beginning of the post-war period. The two largest owners held more than 50 percent of the vote in 85 percent of listed firms (Lindgren 1953), while households remained the dominant ownership category, with 75 percent of all Swedish listed shares (Spånt 1975). When foreign exchange controls were introduced at the onset of the Second World War, foreign owners became increasingly marginalized. These controls entailed a number of measures that restricted foreign ownership of Swedish firms and property. ${ }^{7}$

In addition, the Social Democrats had by this point become firmly established as the leading political force in the country. Although they entertained a vision of a socialist economy in the long-term, the Social Democrats trod a more pragmatic route in the meantime, emphasizing a more equal distribution of income and wealth and discouraging individual wealth accumulation. ${ }^{8}$ Few measures were taken to socialize ownership of firms up through the mid-1970s, a policy termed "the historical compromise" (Korpi 1982). The industrial elite acknowledged, and more or less accepted, that the Social Democrats would use their political power to implement far-reaching welfare reforms, while the labor movement would abstain from socializing the industrial sector. This culture of compromise and negotiations between different elites would hardly have developed (Steinmo 2003; Katzenstein 1985) without the predominance of a few large firms and even fewer ownership groups (Reiter 2003).

Such groupings could have been neither created nor sustained without support from requisite institutions. Tax policy was key in this respect. While financing through debt and retained earnings was strongly favored, individual wealth accumulation was discouraged by the taxation of dividends, capital gains, inheritances and gifts. ${ }^{9}$ This had at least three important effects: (i) transfer of a progressively larger share of control blocks to tax-exempt institutions, notably family trust funds; (ii) a rapid decrease in the number of important ownership groups; ${ }^{10}$ and (iii) a gradual increase in pyramiding and dual-class shares, so that controlling owners could retain control their firms despite the harsh tax treatment.

As shown in Table 1, 18 percent of all listed firms used dual-class shares in 1950; by 1981, that number had increased to 54 percent. The largest firms retained control by means of closed-end

\footnotetext{
${ }^{7}$ The most important measures included (Reiter 2003): the acquisition of Swedish companies required approval from the central bank; no more than 20 percent of the votes or capital of a listed company could be owned by foreign investors; foreign banks were not allowed to establish branches in Sweden; and foreign acquisition of real estate was subject to approval by the regional government.

${ }^{8}$ Some observers have questioned this assertion. However, the party program is quite explicit on this point. Even the 1990 program describes (authors' translation from Swedish): "The Social Democrats strive to make the democratic ideal permeate the entire social order.... To achieve this goal [we] would like to remodel society to the effect that the right to decide on production and its distribution lies in the hands of the people."

${ }^{9}$ The first steps in this direction were taken as early as 1938 . We have analyzed this in detail in earlier works (Henrekson and Jakobsson 2001, 2003, 2005).

${ }^{10}$ The widely cited government commission on Ownership and Influence in Private Industry (SOU 1967:7) identified 17 important ownership groups/families in 1963. Within the next few years, ownership concentration increased considerably; by 1967 the Wallenberg family alone controlled 10 of the 25 largest companies (Glete 1994, p. 289).
} 
investment funds (CEIFs) organized as pyramid holding companies. Crucially, CEIFs enjoy a privileged tax status: capital gains and dividends on their holdings are tax exempt. The most important of these CEIFs were started (or converted) as a result of new legislation in 1934 that prohibited banks from owning stock. New CEIFs, all with close ties to specific banks, ${ }^{11}$ were formed in a second wave in the first half of the 1960s. In 1971, as many as 19 CEIFs were listed on the SSE (Lindgren 1994a). The CEIFs were in turn controlled by a still smaller capital base, grounded in dual-class shares used by the ultimate owners.

Despite the deregulation of credit markets in the 1980s, the use of dual-class shares, pyramiding and numerous takeovers led to a substantial increase in the concentration of ownership control. ${ }^{12}$ The average voting power of the largest single owner in listed companies increased by roughly 15 percentage points from the late 1970s until 1991. Of the 165 firms (out of a total of 202) with votingright differentials of 1 to 10 in 1991, the largest owner held a voting share of 53 percent on average (Isaksson and Skog 1994). ${ }^{13}$

Between 1989 and 1993, the government undertook measures that blew the market for foreign ownership wide open. This led to a rapidly increasing share of foreign ownership; at just 7 percent in 1989 , this share skyrocketed to 40 percent ten years later. Despite this steep increase in foreign ownership, control of the listed companies became even more concentrated at first. Agnblad et al. (2001) document that among the 304 listed companies in 1998, the largest shareholder controlled on average 38 percent of the vote. Furthermore, the controlling owner had more than 50 percent of the vote in 34 percent of firms, and the largest owner had more than 25 percent of the vote in 82 percent of firms. Thus, the typical firm listed on the SSE had one clearly defined controlling owner. In most cases, the controlling owner was a family or a single individual (62 percent of all listed firms).

In order to defend against deregulation's threat to incumbent controlling owners, the use of dualclass shares and pyramiding accelerated. Almost 90 percent of all listed firms had dual-class shares in the early 1990s, and the share of the SSE (market cap) controlled by CEIFs peaked at 83.2 percent in 1993. Thereafter it began to decline, but the CEIFs attempted to offset this by increasing the leverage of their control. Högfeldt (2005) calculates that "the control multiplier" - the total equity value of firms controlled by CEIFs divided by the value of capital invested by the controlling ownersincreased from 17.2 in 1993 to 22.3 in 2000 . Hence, the control was based on an increasingly thin equity base, a feature that distinguished Sweden from other European countries by the late 1990s (Agnblad et al. 2001).

Apparently, the traditional owners managed to fend off the forces of globalization when it came to controlling ownership of public companies. On a general level, this could be ascribed to the very strong and entrenched position these groups held in the relatively small Swedish economy. In her

\footnotetext{
${ }^{11}$ In a detailed analysis of six of these CEIFs, Petersson (2001) documents a total of 111 acquisitions of mostly medium-sized family-owned firms in the 1962-89 period.

${ }^{12}$ Cross-holding arrangements also emerged. Cross holdings hardly existed in the $1970 \mathrm{~s}$, but rapidly gained in importance during the 1980s: In 1988 there were 26 cases among listed companies of cross- or circular ownership, where the companies involved held at least two percent of each other's voting rights (Isaksson and Skog 1994). All cross holdings were dismantled during the 1990s.

${ }^{13}$ It is easy to see why the premium on such control blocks decreased substantially when the mandatory bid rule was introduced in 1999.
} 
empirical study of the Swedish ownership structure in 1990 and 2000, Stafsudd (2009) shows that the owners of Swedish public companies were indeed more closely clustered than in other industrialized countries. She argues that this "small world" feature of the Swedish ownership structure contributes to a norm system that provides a greater degree of investor protection on the Swedish stock market than could be inferred from the formal rules of investor protection. According to Stafsudd the resulting high standards of investor protection have contributed to the high willingness of foreign investors to invest in the Swedish stock market.

As we shall see the success of the defense of the position of traditional owners was transitory. Their position reached its peak in the late 1990s and has after that been in decline. The ownership structure at the beginning of the 2010s is therefore quite different from the one analyzed by Stafsudd (2009).

The Wallenberg family has long been the leading exponent of the Swedish corporate control model. After the turn of the millennium, however, their influence on the SSE clearly began to wane. The decline can be attributed to the factors listed in the previous discussion. By the end of the 1990s, the influence of the Wallenberg sphere reached a kind of zenith. According to the calculations in Agnblad et al. (2001), the Wallenberg group held controlling positions in companies accounting for 42 percent of the market cap of the SSE in 1998. By November 2, 2010, their control had declined to 17.1 percent of the total market cap. ${ }^{14}$ The number of SSE-listed companies controlled by the group had also declined from 14 to 7 (defining control as controlling at least 10 percent of the votes). ${ }^{15}$ It is also explicitly stated in Investor's Annual Report (2010, p. 10) that "[w]e evaluate the long-term return potential of all investments. If our assessment shows that the potential of a holding does not meet our requirements, or is higher in another ownership structure, we look to exit the holding."

\footnotetext{
${ }^{14} 14.2$ percent if only half of Ericsson is included (where control is shared equally with Industrivärden).

${ }^{15}$ Here it should be noted that neither AstraZeneca nor ABB are defined as companies listed on the SSE. Moreover, the Wallenberg voting share is nowadays small in these two companies ( $<4 \%$ in AstraZeneca and $<8 \%$ in $A B B)$.
} 
Table 2 Closed-end Investment Funds' Control of the Stockholm Stock Exchange, 1986-2010.

\begin{tabular}{|c|c|c|c|c|c|c|}
\hline Year & $\begin{array}{r}\text { Value } \\
\text { under } \\
\text { CEIF } \\
\text { control }\end{array}$ & $\begin{array}{r}\text { Value of SSE } \\
\text { (CEIFs } \\
\text { excluded) }\end{array}$ & $\begin{array}{r}\text { \% of SSE value } \\
\text { (CEIFs exclu- } \\
\text { ded) under } \\
\text { CEIF control }\end{array}$ & $\begin{array}{l}\text { Investments on } \\
\text { SSE by controlling } \\
\text { owners of CEIFs } \\
\text { (cash-flow rights) }\end{array}$ & $\begin{array}{r}\text { Investments } \\
\text { as \% of SSE } \\
\text { value }\end{array}$ & $\begin{array}{r}\text { Control/ } \\
\text { capital }\end{array}$ \\
\hline 1986 & 284.3 & 405.5 & 70.1 & 25.0 & 6.2 & 11.4 \\
\hline 1993 & 691.8 & 831.8 & 83.2 & 40.1 & 4.8 & 17.2 \\
\hline 2000 & $1,786.5$ & $3,135.0$ & 57.0 & 80.3 & 2.6 & 22.3 \\
\hline 2005 & $1,579.1$ & $3,077.3$ & 51.3 & 157.5 & 9.1 & 5.6 \\
\hline 2010 & $1,765.2$ & $3,680.5$ & 48.0 & 297.9 & 8.1 & 5.9 \\
\hline \multicolumn{7}{|c|}{ Under Investor/Wallenberg or Industrivärden/SHB control (subset of upper panel) } \\
\hline Year & $\begin{array}{r}\text { Total } \\
\text { value } \\
\text { controlled } \\
\end{array}$ & $\begin{array}{r}\text { Value of SSE } \\
\text { (CEIFs } \\
\text { excluded) }\end{array}$ & $\begin{array}{r}\% \text { of SSE value } \\
\text { controlled }\end{array}$ & $\begin{array}{l}\text { Investments on } \\
\text { SSE by two groups } \\
\text { (cash-flow rights) }\end{array}$ & $\begin{array}{r}\text { Investments } \\
\text { as \% of SSE } \\
\text { value }\end{array}$ & $\begin{array}{r}\text { Control/ } \\
\text { capital }\end{array}$ \\
\hline 1986 & 214.2 & 405.5 & 47.6 & 14.5 & 3.2 & 14.8 \\
\hline 1993 & 561.7 & 831.8 & 62.9 & 32.7 & 3.7 & 17.2 \\
\hline 2000 & $1,632.4$ & $3,135.0$ & 49.3 & 69.7 & 2.2 & 23.4 \\
\hline 2005 & $1,171.5$ & $3,077.3$ & 38.1 & 111.8 & 7.2 & 6.1 \\
\hline 2010 & $1,338.7$ & $3,680.8$ & 36.3 & 195.5 & 5.3 & 6.8 \\
\hline
\end{tabular}

Note: All values are in billion SEK. For 2005 and 2010 the following CEIFs have been included: Investor (+ direct control by Wallenberg Foundations); Industrivärden, Latour, Säki, Melker Schörling AB (2008 and 2010 only), Lundbergs, Kinnevik, Traction, Skanditek (for 2005), Bure and Öresund.

Source: Högfeldt (2005, Table 9.6) for 1986, 1993 and 2000; Fristedt and Sundqvist (2006) for 2005 and SIS Ägarservice and own calculations for 2010.

Table 2 details how CEIF control of firms listed on the SSE has evolved since the mid-1980s. As already noted, CEIF control was accentuated in response to deregulation and the step-by-step integration of financial markets in 1989-93. In 1993, the share of the market cap of the SSE controlled by CEIFs peaked at 83 percent, and the two leading CEIFs-Investor controlled by the Wallenbergs and Industrivärden controlled by interests with close ties to Svenska Handelsbanken (SHB)-controlled 63 percent. The combination of pyramiding and dual-class shares created a substantial control multiplier (total equity value of firms controlled by CEIFs divided by the value of capital invested by the controlling owners), which grew over time until it peaked in 2000 at roughly 23. Since then, CEIF control has declined substantially. By 2010, CEIFs controlled less than half of the SSE, and the combined Investor/Industrivärden share had declined to 36 percent. The control multiplier was down to 6 , a decline by close to three fourths from its peak in the year 2000 . Thus, the development after 2000 is in line with the main thrust of the preceding section. 


\section{The Revival of the Swedish Stock Market and the Creation of New Swedish Billionaires}

Rajan and Zingales (2001) observed that in many industrial countries, financial markets were better developed in the early $20^{\text {th }}$ century than in 1980 . Using stock market capitalization as a share of GDP as an indicator of such development, they show that this ratio exhibits a long U-curve during the $20^{\text {th }}$ century in most of today's wealthiest countries. The high values in the ratio at the beginning of the century were followed by a "reversal" towards less developed financial markets and lower market capitalization as a share of GDP. Then there was a "revival" beginning in the late 1970s for most countries. Later, in the 1990s, the ratio exceeded the values in 1913. In Sweden, the U-curve was particularly pronounced. While the countries in the Rajan-Zingales sample had on average a minimum U-curve of around 28 percent (Table 3), the Swedish U-curve's minimum reached as low as 9.5 percent in the late 1970s. The maximum, attained at the turn of the millennium, was also substantially larger than the average for the group of countries (Figure 2). As Rajan and Zingales point out, both the reversal and the revival can be explained by major policy changes.

Table 3 Stock Market Capitalization as a Share of GDP in a Sample of Industrialized Countries (selected years 1913-1999).

\begin{tabular}{rrrrr}
\hline 1913 & 1950 & 1980 & 1990 & 1999 \\
\hline 0.54 & 0.27 & 0.28 & 0.68 & 1.38 \\
\hline
\end{tabular}

Note: The following countries are included: Australia, Canada, Denmark, France, Germany, Italy, Japan, the Netherlands, Norway, Sweden, Switzerland (n.a. for 1950), the U.K. and the U.S.

Source: Rajan and Zingales (2003).

Figure 2 Stock Market Capitalization as a Share of GDP, Sweden 1908-2010.

Enclosed

Source: Waldenström (2002), Statistics Sweden and NasdaqOMX.

The reversal was brought about by a general trend towards increased regulation of markets and decreased openness to trade and cross-border financial flows. The revival, on the other hand, arose out of the wave of market deregulations that swept the world during the Thatcher-Reagan era.

This was certainly true for Sweden as well, at least on a general level. The very low minimum point for Swedish stock market capitalization can likely be traced to regulation that went further than in most other countries (Jonung 1994; Lindbeck 1997). In addition, Sweden pursued policies that were openly hostile towards private wealth accumulation for a substantial period of time. ${ }^{16}$

The revival of financial markets constitutes our main focus here. In particular, we are interested in the effects of this revival on wealth formation and the emergence of investors sufficiently wealthy to constitute the basis for controlling ownership of large listed companies.

\footnotetext{
${ }^{16}$ See, e.g., Henrekson and Jakobsson (2001), Johansson and Magnusson (1998) and Lindbeck (1997).
} 
The low overall market cap in Sweden during the 1960s and 1970s entailed a very low valuation of listed companies, a non-increasing number of listed companies and depressed stock market activity. The price-earnings ratio hovered around 4 during the 1970s; Tobin's q fell as low as 30 percent; and there were few IPOs, few new issues by existing companies, and very few takeovers (an average of four takeover bids per year in the 1970s). The stock market was largely irrelevant as a source of finance and corporate restructuring. ${ }^{17}$

The revival had multiple causes. Overall, a political sea change transpired. After a long period when more regulation and more state intervention were considered both desirable and inevitable, the international tide turned towards deregulation and increased market liberalism. Sweden did not remain unaffected by this trend.

The march towards a more regulated and ultimately socialist Swedish society was epitomized by the wage-earner fund proposal-a scheme advocated by the blue-collar workers' union LO and the Social-Democratic Party. The plan called for most of the ownership of the corporate sector in Sweden to be gradually transferred into collective funds governed by the trade unions. ${ }^{18}$ The heyday of this fund proposal coincided with the low point of the stock market cap as a share of GDP. Conversely, the start of the revival of the stock market roughly coincides with the point at which the wage-earner funds were removed from the political agenda.

The actual reforms came in two waves. The first wave began in the 1980s and included a complete deregulation of the financial markets, including both domestic markets and cross-border financial flows. ${ }^{19}$ The second wave consisted of a major overhaul of the tax system. These reforms were similar to the reforms in the United States, although aggregate taxation remained at the same high level as before. Key product markets were also deregulated in the second wave, notably telecom, air transport, postal services and electricity, and the provision of key tax-financed services was made contestable (Bergh and Erlingsson 2009).

A special feature of the Swedish reform was that taxation of capital income was treated separately and taxed at a flat rate of 30 percent. However, the tax reform did not result in a completely neutral tax system, but rather a tax system that was considerably more neutral and market friendly than before.

These reforms paved the way for a dramatic revival of the Swedish financial markets, many of which had been practically defunct. During the 1980s, the index (AFGX) of the SSE increased twelve-fold, compared to a mere three-fold increase in the Dow Jones index. After 1990, however, the development of the AFGX began towing the line set by the Dow Jones index. Nevertheless, the index of the SSE increased by 56 times between January 1980 and January 2000, more than five times more

\footnotetext{
${ }^{17}$ See Henrekson and Jakobsson (2005, p. 220) and the further references contained therein,

${ }^{18}$ For a further description, see Pontusson (1992). The original proposal is presented in Meidner (1978).

${ }^{19}$ The revival of the stock market in the 1980s was aided by a number of asymmetries in the tax system, which became particularly potent when the domestic credit market was deregulated. Nominal interest payments were fully tax deductible until 1981 against the marginal tax rate and thereafter at a rate of 50 percent. At the same time, 60 percent of capital gains on long-term stock holdings ( $>2$ years) were tax exempt, and beginning in the late 1970s, the government introduced stock market savings schemes that were tax exempt for households.
} 
than in the U.S. and the U.K. during the same period. ${ }^{20}$ This surge created a dynamism on the stock market that had been absent before. IPOs exploded into 352 new listings between 1979 and 1997 (Holmén and Högfeldt 2005b), despite there being few, if any, during earlier decades. Takeover activity also increased dramatically. Between 1980 and 1992, 253 takeover bids occurred among firms where both bidders and targets were listed on the SSE, of which 212 were successful (Agnblad et al. 2001).

Following the removal of all foreign exchange controls and all barriers to foreign ownership of Swedish firms and real estate, the foreign ownership share of Swedish listed companies increased rapidly. When controls were lifted, the foreign ownership share was 7 percent. Ten years later it had increased to 40 percent.

Generally, the deregulation of the Swedish financial markets provided ample opportunities for new actors on the market to pursue corporate control. All of a sudden, new fortunes could be created in other sectors and subsequently be used as a basis for value-creating stock market activities.

The sheer growth of the stock market suggests that a large increase in individual wealth in Sweden should have also taken place. With a 56-fold increase in the stock market return index, even moderate holdings of wealth could be turned into significant holdings just by riding the index. For active and successful entrepreneurs, the gains could be far larger, an important factor in driving new controlling owners on the SSE. If everyone just held on to their shares during the surge, individual fortunes and the valuation of firms would have increased in parallel. In this case, however, there would have been little scope for new controlling owners. Instead we would expect the new dynamism of the stock market to create a climate where successful entrepreneurs could increase their wealth far more than the general upswing in the stock market. The resulting list of new blockholders provides compelling evidence that this took place.

Roine and Waldenström (2011) offer direct evidence that the surge in the stock market had unique importance for private wealth formation during the period. They study the contribution of capital gains to total income of people in the top percentile of the income distribution and find a remarkable increase in the contribution of capital gains. They also demonstrate a close correlation between the contribution of capital gains and stock market development. The contribution is unique both in a historical and international perspective (Figure 3).

Figure 3 Ratio of Top Percentile Income Share with and without Capital Gains in Selected Countries, 1980-2006.

Enclosed

Source: Roine and Waldenström (2011).

\footnotetext{
${ }^{20}$ Data sources: Affärsvärlden for AFGX, NasdaqOMX for OMX30 and WREN Investment Advisers for the FTSE and the Dow Jones indices.
} 
More specifically, the great stock market revival (1980-2000) created a number of individual fortunes that were large enough for their holders to act as controlling owners on the SSE. Table 4 lists all individuals who are/were blockholders on the SSE during the period 2000-2010, where the wealth of the individuals/families was created after 1979 and registered net personal wealth exceeded SEK 1 billion at some point in 2007-09.

Moreover, the revival of the stock market has boosted the position of wealth for a number of individuals who are first or second generation industrialists/entrepreneurs, but who founded their wealth before 1980. One can mention Fredrik Lundberg with family (Holmen, Lundbergs, Hufvudstaden, Cardo; SEK 18 billion), Dan Sten Olsson and family (Concordia, Beijer Electronics, Midelfart Sonesson, Gunnebo; SEK 24 billion), Antonia Ax:son Johnson, (Mekonomen, Axfood; SEK 45 billion), Erik and Mats Paulsson (Peab, Skistar, Brinova; SEK 6.3 billion), Jörn, Finn and Kirsten Rausing (Alfa Laval; SEK 120 billion), Stefan Persson and family (H\&M; SEK 225 billion), and Jenny Lindén (daughter of Ulf G. Lindén; Beckers, Höganäs, Regnbågen, Transatlantic; SEK 3.2 billion). ${ }^{21}$

A number of people have become billionaires by working in private equity (Björn Savén, Robert Andréen, Conni Jonsson), in the financial sector (Patrik Brummer, Peter Thelin, Per Josefsson), or as entrepreneurs in unlisted firms (Rune Andersson, Bo Larsson, Bo and Ulf Eklöf, Christer Ericsson, and several others). There are also a number of first or second generation Swedish entrepreneurs who are extremely wealthy but have chosen to live abroad, investing little of their wealth on the SSE. First and foremost this includes Ingvar Kamprad (founder and sole owner of IKEA with an assessed wealth of SEK 450 billion), Hans Rausing with family (former co-owner of TetraPak, SEK 56 billion), Bertil Hult (founder and sole owner of EF Education, SEK 15 billion), and Roger Akelius (real estate entrepreneur, SEK 10 billion). ${ }^{22}$

\footnotetext{
${ }^{21}$ From the Swedish business magazine Veckans Affärer's list of billionaires as of October 2010: http://www.va.se/nyheter/bildspel/2010/09/sveriges-miljardarer/. The total number of Swedish billionaires (in SEK) was estimated to be 106 in 2010. Amounts in parentheses pertain to total net wealth, not to wealth of blockholdings in the listed companies.

${ }^{22}$ From Veckans Affärer's list of billionaires as of October 2010: http://www.va.se/nyheter/bildspel/2010/09/sveriges-miljardarer
} 
Table 4 Blockholders on the SSE with Personal Wealth Exceeding SEK 1 Billion in 2007-09, Fortune Founded after 1979, and Companies Controlled.

\begin{tabular}{|c|c|c|c|}
\hline Family/person & Year founded & $\begin{array}{r}\text { Net worth } \\
\text { (billion SEK) }\end{array}$ & Companies founded or controlled \\
\hline Arnhult, Rutger & 1987 & 3.3 & Corem Property Group, M2 Gruppen \\
\hline Arnhög, Mats & 1980 & 2.0 & Active Biotech, MGA Holding \\
\hline Bennet, Carl & 1989 & 5.1 & Elanders, Getinge \\
\hline Bjäringer, Martin & 1990s & 1.3 & Björn Borg, Doro \\
\hline Brandberg, Christer & 1981 & 1.6 & Axis, Senea \\
\hline Douglas, family & 1980 & 22.5 & Latour, Säkl, Assa Abloy, Securitas \\
\hline Elam Håkansson, Peter & 1997 & 1.0 & East Capital \\
\hline Hagströmer, Sven & 1981 & 1.7 & Öresund, HQ Bank, Avanza \\
\hline Hansen, Johan & $1990 \mathrm{~s}$ & 2.6 & Rörvik Timber \\
\hline Holmström, Birgitta & 1990 & 1.5 & Atrium Ljungberg \\
\hline Ljungberg, Åke & 1990 & 1.5 & Atrium Ljungberg \\
\hline Hopkins, Thomas & 2000 & 1.1 & Realia \\
\hline Hörnell, Erik & 1999 & 1.3 & Ongame \\
\hline Jansson, Torsten & 1990 & 1.7 & New Wave \\
\hline Johansson, Sven-Olof & 1988 & 1.2 & Fast Partner \\
\hline Karlsson, Therese & 1984 & 1.1 & Axis \\
\hline Lidell, Claes & 1999 & 1.3 & Ongame \\
\hline Lindqvist, Bertil & 1984 & 1.2 & PA Resources \\
\hline Norfeldt, Sven & 1988 & 1.4 & Capinova, Riddarhyttan \\
\hline Perlhagen, Carl & 1991 & 1.1 & Meda \\
\hline Qviberg, Mats & 1990 & 1.0 & Öresund, HQ Bank, Avanza \\
\hline Schörling, Melker & 1987 & 10.0 & $\begin{array}{l}\text { MSAB, Hexagon, Hexpol, Assa Abloy, } \\
\text { Securitas; Aarhus Karlshamn, Bong }\end{array}$ \\
\hline Selin, Erik & 1992 & 9.3 & Balder/Din Bostad \\
\hline Ström, Anders & 1993 & 1.2 & Unibet \\
\hline Tigerschiöld, Dag & 1980 & 1.1 & Skanditek \\
\hline Weil, Robert & 1980 & 3.0 & Proventus \\
\hline Ågerup, Bengt & 1987 & 1.9 & Q-Med \\
\hline
\end{tabular}

Note: In most cases net worth is for 2009. Companies founded/controlled are taken from Fristedt and Sundqvist $(2008,2009)$ and from Waldenström (2010). In several cases the control block has been sold.

Source: Waldenström (2010) and Roine and Waldenström (2009).

\section{The (Relatively) Weak Position of Management in Swedish Firms}

The obvious alternative to the Swedish blockholding model, and the one we would expect had there been convergence to the Anglo-American corporate governance model, would be dispersed ownership and management control. So why is this model still so rare among Swedish listed companies.

Institutional investors have continuously increased their share of financial savings available for stock market investment; by 2009 their predominance was overwhelming. Figure 4 provides a stark 
illustration of this state of affairs, showing that more than 100 percent of all financial savings in the household sector exist in the form of life insurance and collective pension savings.

Figure 4 Financial Household Savings as a Share of Disposable Income in Sweden, 1995-2009 (\%).

Source: Statistics Sweden.

Three categories dominate: (1) pension funds with a corporatist or government affiliation; (2) strictly private pension funds; and (3) mutual funds. Institutional investors have not acted as blockholders for a number of reasons. Many are restricted from assuming this role by law (such as the Swedish National Pension Funds Act) or by internal rules. The national pension funds (AP1-4), for example, are not allowed to exceed 10 percent of the votes in a company. The corporatist funds do not have any formal rules banning them from exceeding that level, but their policy is such that they avoid being represented on the board. ${ }^{23}$ Moreover, blockholding would probably be an obstacle to maximizing the returns on their investments. We have already pointed to the economic costs associated with blockholding, arguing that the discount on CEIFs reflects this cost.

In short, intrinsically passive capital and strong de facto minority protection abound on the Swedish stock market, while the traditional model of corporate control is on the retreat. It would be natural to conclude that the Anglo-American model of dispersed ownership and management control (or greater board independence) would assume a larger role in light of this state of affairs. So why do we see so little of it among listed Swedish companies?

The theoretical argument underpinning management control's continuing dominance suggests that it is not rational for any particular owner to assume the laborious and costly task of controlling the company. Therefore, dispersed ownership leads to management control by default. The finance literature has concentrated on the principal-agent problem caused by the separation of ownership from control (Tirole 2006, ch. 1). Less focus has been given to the question of whether or under which conditions management control becomes a viable option. One exception is Roe (2003), who argues that the Anglo-American model is not viable in an economy where the labor movement is politically dominant. In such a political environment, he argues, management cannot uphold the strictly commercial interest of the shareholders against the firm's employees and other stakeholders. Roe often uses Germany as an example to exemplify his point. With the unions holding a 50 percent share of board representation, a strong owners' representation on the board is a necessity.

Although his argument is not completely convincing, it receives empirical support. There are several ways to quantify the degree of leftism, or political strength of labor in a country. However measured, Roe finds a strong positive correlation between political leftism and ownership concentration among wealthy countries.

\footnotetext{
${ }^{23}$ Regarding non-government stock-market funds the law stipulates that no fund is allowed to acquire stock in a specific company to such a degree that the concomitant control rights "gives the fund a significant influence on the governance of the company." [Lag (2004:46) om investeringsfonder 5 kap. $19 \S$, authors translation.]
} 
In Roe (2003, ch. 11) Sweden emerges as a country where the influence of labor is at its strongest and ownership concentration (as measured by control rights) is greater than in most other countries. Henrekson and Jakobsson $(2001,2005)$ demonstrate that Social-Democratic governments determinedly pursued a policy that fostered the concentration of corporate control. Since the beginning of the 1990s, however, these policies have become more neutral. Still, certain features of the policy package remain that work against an expansion of managerial control and dispersed ownership.

Different kinds of managerial incentive systems aimed at aligning the interests of management and shareholders constitute important features of corporate governance in Anglo-American firms with dispersed ownership and management control. ${ }^{24}$ In Sweden, a high tax rate on labor income and the tax treatment of stock options tied to employment make it very difficult and costly to implement powerful incentive systems. ${ }^{25}$ Moreover, even if they were to be implemented, they would be in conflict with the highly egalitarian values that characterize the Swedish public discourse. Roe identifies this as one reason why management control will not work in highly "social-democratic" societies.

Roe argues that the difficulties involved in upholding the principles of shareholder value in a firm controlled by management in a "social-democratic" country invite the conclusion that management controlled firms get a lower valuation in such an economy. This in turn encourages takeover bids from firms using other modes of corporate governance. That being said, Roe does not specify the link between the weak position of management in social-democratic economies and actual outcomes in the market.

Importantly, Swedish corporate law gives a firm's management a much weaker position vis-à-vis the owners than in U.S. firms, where the board mainly consists of insiders topped by a CEO acting as chairman of the board. Hence, the management in American firms can take action to defend itself in a potential takeover situation; corporate law even imposes a fiduciary duty to defend the firm. For example, management may be able to acquire proxy votes for its own defense and use a shareholder rights plan (poison pill) to make a takeover more expensive, a strategy that is unheard of in Sweden. Management in the U.S. system also uses staggered boards as a defense. When boards are staggered, individual board members are elected for more than one year; only part of the board (usually one third) are newly elected each year.

The U.K. is the other leading market characterized by dispersed ownership of public firms. Still, in key respects the U.K. system works differently from its American counterpart. Although shareholders are accorded significant participatory rights in corporate governance, the courts have rejected a view of shareholders as owners/principals (Hill 2010). At the same time, the legal system is very restrictive towards poison pills and other frustrating actions of the board ("board neutrality") and stresses shareholder rights during takeovers through mandatory takeover bids. Under normal circumstances, the board has a strong position, consisting of a mix of insiders (normally the CEO and CFO) and

\footnotetext{
${ }^{24}$ More generally, the Anglo-Saxon model is characterized by dispersed ownership, strong minority protection, strict insider trading prohibition, strict disclosure rules, well-developed financial markets, managers incentivized to maximize shareholder value for current shareholders, no co-determination, no governance role for banks, and arm's length relationship to creditors.

${ }^{25}$ See Ohlsson (2006).
} 
independent non-executive directors. The latter propose new directors to the AGM, typically elected for several years with staggered terms. This severely curtails shareholders' immediate influence except in the case of takeover bids. At least half of the outside directors must be independent of any major shareholders. ${ }^{26}$

The Swedish system is starkly different from that of the U.S. and the U.K. In Sweden, the entire board is up for reelection every year. Therefore, anyone who can muster a majority of votes at the Annual General Meeting of Shareholders (AGM) can elect a new board, which can in turn displace the current management. ${ }^{27}$ The CEO is the only inside director, and even s/he is not mandatory. In 2009 the CEO was not on the board in 55 percent of the public firms in Sweden (Fristedt and Sundqvist 2010).

When a Swedish firm has a controlling owner, the CEO enjoys a strong position as long as $s /$ he is backed by the owner. The situation changes dramatically if ownership is dispersed. The subordinated position of management in Swedish listed firms vis-à-vis the board and the firm's owners makes it very difficult for management to build a strong position by striking bargains with important groups of firm owners. The weak position of management relative to shareholders also makes Swedish public firms with dispersed ownership amenable to takeover bids. Nachemson-Ekwall (2010) asserts that the fact that the committee that nominates board members for one-year terms is wholly made up of shareholders, combined with the board's passive stance during takeover-bids (in line with the U.K. takeover rules), leaves companies with dispersed ownership unable to protect themselves against hostile takeover bids. According to Nachemson-Ekwall (p. 17), "short-termism among institutional investors can have very profound effects on the governance of a company in a hostile takeoversituation, as the actors' activity relate to a strict financial index-tracking or portfolio logic leaving the corporation aside." $^{28}$

Pacces (2007) concludes in his comparative study of five countries that Swedish corporate law makes dispersed ownership with management control unviable. Roe's prediction of dominance for ownership control in a political environment like the Swedish one is thus reinforced by the weak formal position given to management by Swedish corporate law. In fact, and as stressed repeatedly by Pacces (2007), the Anglo-American model necessitates a degree of entrenchment for management (or the board) to function. In the wake of corporate scandals shareholder rights are being strengthened, thus diminishing the degree of entrenchment for management/boards in the U.S. (Hill 2010). This is one likely reason for the sharp decline in the number of listed firms also in the U.S. in the last 15 years (Wield and Kim 2009)

The openness of the system also offers opportunities for special interests to profit. As Carlsson (2007) indicates, foreign institutional investors have at times chosen not to take a seat on the

\footnotetext{
${ }^{26}$ See, e.g., Jackson and Miyajima (2007) and Armour and Skeel (2007) for a description and comparison of the U.S. and U.K. systems, and Barca and Becht (2001) for a broad comparison with the governance models on the European continent. However, there seems to be a shift away from the board neutrality position regarding takeovers in the U.K. in favor of providing management with greater discretion to block takeovers in certain circumstances. See U.K. Takeover Panel (2010).

${ }^{27}$ Carlsson (2007) explains in some detail the rules governing the relationships between management, the board, shareholders and the AGM in Swedish public firms.

${ }^{28}$ Kallifatides et al. (2010) study the takeover of Skandia by Old Mutual in 2005 is in depth to make this point.
} 
nomination committee, even though the size of their ownership stake warrants them such a position. Short-term activists have been known to borrow shares to boost their influence when the nomination committee is constituted in order to promote board candidates who will favor measures deemed to boost the short-term stock return, including a more leveraged capital structure, higher dividends, and share repurchase programs.

As a result, there is a very low proportion of firms without a dominant blockholder on the SSE. This is demonstrated in Table 5, which gives the share of listed firms without a controlling owner on the SSE for selected years from 1988 to 2010.

Table 5 The Importance of "Ownerless" Firms on the SSE, 1988, 1993, 1998, 2003, 2008 and 2011.

\begin{tabular}{|c|c|c|c|c|c|c|}
\hline & 1988 & 1993 & 1999 & 2003 & 2008 & 2011 \\
\hline No. of listed firms & 239 & 194 & 316 & 301 & $271 *$ & $234 *$ \\
\hline No. of ownerless firms & 5 & 7 & 9 & 31 & 23 & 19 \\
\hline $\begin{array}{l}\text { Total market cap of SSE } \\
\text { (billion SEK) }\end{array}$ & 618 & 893 & 2,368 & 2,115 & 2,091 & 4,412 \\
\hline $\begin{array}{l}\text { Market cap ownerless } \\
\text { firms (billion SEK) }\end{array}$ & 90.5 & 95.7 & 27.4 & 15.6 & 35.6 & 131.1 \\
\hline Share of total no. (\%) & 2.1 & 3.6 & 2.8 & 10.3 & 8.5 & 8.1 \\
\hline Share of market cap (\%) & 14.7 & 10.7 & 1.16 & 0.73 & 1.70 & 2.97 \\
\hline
\end{tabular}

Note: A firm is defined as ownerless if no shareholder has at least $10 \%$ of the votes or equity. The large decline in the value of ownerless firms between 1993 and 1998 is largely explained by the fact that Volvo and SEB got a dominant owner in this period (Renault S.A. and Investor, respectively). *The number of listed firms is smaller than in table 1 because firms listed on the NGM list are excluded. Data for 2011 are for February 16, 2011. Source: Sundqvist (1989), Sundin and Sundqvist (1994, 1999), Fristedt and Sundqvist $(2004,2009)$ and SIS Ägarservice.

\section{The Rapidly Expanding Alternative Control Models}

In the preceding section we documented the ongoing retreat from the traditional Swedish corporate governance model based on "old capital" and a large wedge between control rights and cash-flow rights. Nevertheless, the model is still dominant on the SSE, although there is far less pyramiding and use of dual-class shares. Hence, the possibility of wielding control based on a narrow capital base is eroding, while a governance model with a controlling owner (blockholder) continues to dominate among listed firms. Indeed, the viable alternatives to the traditional control model are to be found outside the realm of listed companies. In this section we will examine two such forms of corporate governance that have been growing rapidly in importance.

In the first one, the firm is a subsidiary to a foreign company, which is often a listed company in its home country. Before the Swedish financial markets were deregulated, severe obstacles to foreign ownership were in place. So while Swedish multinationals had a large portion of their operations abroad in the form of offshore subsidiaries, foreign ownership in Sweden was very limited. Domestic credit markets were fully deregulated by 1986 and the deregulation of capital markets, including restrictions on foreign ownership, was completed in 1993. The result was a large inflow of capital, and a substantial increase in the foreign ownership share. This is illustrated by Figure 5 . 
Figure 5 The Stock of Inward FDI as a Share of GDP in Sweden and the OECD, 1980-2009 (\%).

Source. UNCTAD (various years).

When foreign ownership takes the form of an acquisition in which the Swedish firm becomes a subsidiary to a foreign parent company, the firm undergoes fundamental changes in governance and structure. Suppose that Swedish firm A is acquired by foreign firm B. Before the acquisition, the Swedish firm is a global company with subsidiaries in several countries. After the acquisition, a new group is formed with its headquarters (usually) in the domicile of parent company B. The Swedish activity in company $A$ will take place within a newly formed subsidiary of the group owned by parent company $B$. The former subsidiaries of $A$ will be integrated in the international network of $B$. Normally, the Swedish operations of $A$ will form a part of this integration. The new group will be listed in the domicile of B, while A is delisted from the SSE. A large number of Swedish firms have been transformed in this way during the last couple of decades. As Figure 6 illustrates, the share of private sector employment in foreign-owned firms increased from 10 percent in the mid-1990s to almost 25 percent in 2009. In firms with more than 200 employees, the share of employment in foreign-owned firms is as large as 41 percent (2005). ${ }^{29}$

Figure 6 Employees in Foreign-Owned Firms in Sweden and Their Share of the Number of Employees in the Swedish Private Sector, 1980-2009.

Source: Strandell (2000) and Swedish Agency for Growth Policy Analysis (2010).

The other rapidly expanding form of corporate governance is private equity (PE). An important part of PE activity involves buyouts of listed companies, thereby turning them into private companies. The buyout is usually the starting-point of a process of restructuring and a possible partition of the target firm. After restructuring, the firm can be sold or, in some cases, reintroduced onto the stock market (Kaplan and Strömberg 2009). PE is more important in Sweden than in all other European countries exception of the U.K. (Tåg 2011). Several Swedish firms specialize within this sector, managing upwards of SEK 204 billion in 2006. Accounting for typical leveraging, this implies a total investment capacity of some SEK 700 billion. The total number of employees in firms controlled by Swedish PE companies was estimated to be roughly 850,000 in 2008 . Although most of these PE-controlled firms will eventually be sold or reintroduced on the stock exchange, they will not necessarily be introduced on the SSE.

The growing importance of PE is illustrated in Table 6, which gives the estimated number of employees in Swedish PE-backed firms for 2004 and 2008. The number of venture capital firms decreased somewhat between 2004 and 2008; at the same time, however, the number of buyout firms sharply increased from 113 in 2004 to 173 in 2008. The buyout category is of prime interest

\footnotetext{
${ }^{29}$ Bjuggren and Johansson (2008). The figure includes employment in all foreign companies with a foreign ownership share exceeding 50 percent. It may also be noted that in 201040 percent of the 500 largest firms in Sweden had their corporate headquarters located outside Sweden (Henrekson and Öhrn 2011)
} 
here. It was estimated in 2008 that close to 7 percent of business sector employment was in PEbacked firms.

Table 6 The Importance of Swedish Private Equity Ownership in the Swedish Business Sector, 2004 and 2008.

\begin{tabular}{|c|c|c|c|c|c|c|c|}
\hline \multirow[b]{2}{*}{ Year } & \multicolumn{3}{|c|}{$\begin{array}{l}\text { No. of employees in Sweden } \\
\text { (1000s) }\end{array}$} & \multirow{2}{*}{$\begin{array}{l}\text { Share of } \\
\text { Swedish } \\
\text { business } \\
\text { sector } \\
\text { employm. }\end{array}$} & \multicolumn{3}{|c|}{$\begin{array}{l}\text { No. of employees in other } \\
\text { countries (1000s) }\end{array}$} \\
\hline & capital & Buyout & Total & & capital & Buyout & Total \\
\hline 2004 & 5.3 & 112 & 117.3 & $4.6 \%$ & 13.2 & 393 & 406 \\
\hline 2008 & 12.6 & 167 & 179.6 & $6.6 \%$ & NA & NA & 674 \\
\hline
\end{tabular}

Source: Swedish Venture Capital Association (SVCA).

An assessment of the number of employees in PE-owned companies before 2004 is presented in Table 7. Roughly 80 percent of the employees worked in buyouts, while the remainder held positions in VC-backed firms. The number of employees outside Sweden in 2002 was estimated to be 100,000 in 2002 (no estimates are available before that date).

Table 7 The Number of Employees in Private Equity-owned Companies in Sweden (Venture Capital plus Buyouts), 1992-2002.

\begin{tabular}{rrrrrrrr}
\hline 1992 & 1993 & 1994 & 1995 & 1996 & 1997 & 2001 & 2002 \\
30,600 & 36,100 & 42,600 & 50,300 & 59,300 & 70,000 & 147,000 & 150,000 \\
\hline
\end{tabular}

Source: Isaksson (1999) and Nutek and Swedish Venture Capital Association (2003).

There are a number of reasons why PE has grown in importance (Jensen 2007). Two aspects stand out as particularly important in the Swedish context. First, there is more freedom as regards nondisclosure of compensation terms, which is particularly important in a highly egalitarian political environment (Roe 2003; Carlsson 2007). Hence, the PE firms have much greater scope for using highpowered incentives to attract talent for both executive and board positions. Second, by legally domiciling the PE funds in tax havens, these incentive schemes are much more tax efficient compared to public firms.

\section{The Decline of the Swedish Stock Market-A New Reversal?}

We have discussed four models of corporate control that are relevant to the Swedish scene:

1. Control by blockholder.

2. Dispersed ownership with management control.

3. Subsidiary to a non-Swedish parent. 


\section{Private equity control.}

Numerous finance scholars have predicted that the globalization of financial markets will lead to a general convergence of corporate governance towards the Anglo-American model, thereby substituting the first for the second model. Indeed, we find that it has become more difficult to use dual-class shares and pyramiding to exercise control of Swedish listed companies. Consequently, the old controlling groups among Swedish investors have seen their influence decline. Yet the decline has to some extent been countervailed by an inflow of new wealthy capitalists who appeared as the stock market surged, offering a more propitious environment for building firms to a sufficient size for becoming public. As a result, the base for the blockholder model in Sweden has broadened. The surge in private wealth during the 1980s and 1990s was, however, a one-time event, and the inflow of new capitalists has since abated. The forces of globalization are still working against the blockholder model.

According to the convergence hypothesis, Model 2 should grow in importance. But, as we have demonstrated, Model 2 is not viable in the Swedish environment of corporate control. There is a very small-and declining - share of companies in the Model 2 category on the SSE. Instead, Models 3 and 4 have grown rapidly in importance. Neither of these two models entails listing on the SSE. Hence, after the one-time surge in private wealth during the 1980s and 1990s, the overall importance of the stock market for the Swedish economy should begin to decline. There are at least two pieces of evidence that indicate such a decline. The most straightforward indication is given by Figure 2 above, which depicts stock market capitalization as a share of GDP over time. The deregulation and international integration of financial markets clearly led to a dramatic surge in the market cap as a share of GDP, peaking in 1999. Since then the trend has been declining, which is in line with our hypothesis, although the short time period and high market volatility makes it difficult to draw strong conclusions.

The market cap as a share of GDP does have one drawback, however-it is highly dependent on the valuation of the stock market. The sharp increase in the $1980 \mathrm{~s}$ and $1990 \mathrm{~s}$ as well as the more recent downturn in the market cap is partly explained by changes in stock prices. Of interest to us here, though, is whether the decrease can be explained by the relative importance of listed firms in the economy.

In order to determine whether this is taking place, we split the changes in the market cap into two parts: (i) changes as a result of price changes in listed stock and GDP, and (ii) "real" changes reflecting changes of domestically listed companies in the economy. In doing this, we deflate the SSE market cap by the stock market index and GDP by the GDP deflator. An analogous calculation is done for the U.K. (FTSE). The result is presented in Figure 7, which documents a marked decline in the "real" market cap in Sweden since the late 1990s. We interpret this decline as a decrease in the real weight of the stock market in the Swedish economy. By contrast, no corresponding decline can be seen in the U.K. Instead, the size of the stock market appears to be relatively constant over time. Moreover, a direct comparison of the evolution in Sweden and the U.K. during the whole period indicates a sharp relative decline of the importance of the Swedish stock market (bold line, right hand scale). 
Figure 7 Real Market Cap as a Share of Real GDP, Sweden and the U.K., 1979-2009.

Note: The market cap has been deflated by the stock market index and nominal GDP by the GDP deflator. Source: Affärsvärlden for AFGX, NasdaqOMX for OMX30, World Federation of Exchanges (WFE ) for the FTSE index and National Accounts data from the OECD.

The second piece of evidence indicating a declining importance of the SSE comes from an investigation of the 100 largest companies in Sweden (in terms of employment). The investigation covers the years 1990, 2000 and 2009, and includes data on total employment, employment in Sweden, whether the firms are listed or not and to which ownership category they belong. Our key findings are presented in Tables 8 and 9. The number of listed firms among the 100 largest is decreasing, while the number of foreign-owned firms and private non-listed firms is increasing. Taken together, the two latter categories outnumbered the listed firms in 2009. Table 9 shows that employment in listed firms among the top 100 is also declining. ${ }^{30}$ This decline is partly a natural consequence of the internationalization of corporate ownership. However, between 2000 and 2009, total employment in listed firms among the top 100 experienced a decrease as well. This accords with the hypothesis of a declining stock market after the 1999 peak.

The number of employees is used as a proxy for value added in the firm, which is not reported in the database. Unfortunately, the increase in world-wide total employment is largely driven by the explosive growth in employment in Securitas since the 1990s. As shown in Table 10, employment in Securitas increased by almost 250,000. Hence, Securitas alone accounts for roughly one fourth of total employment in the large listed firms in Table 8. Since Securitas is a low capital intensity service provider, value added per employee is low in this firm compared to other large Swedish firms. The same is true for $\mathrm{H} \& M$, although to a lesser extent. Therefore, Table 8 exaggerates the importance of the SSE for the Swedish economy in the year 2009; the decline from the year 2000 is also more pronounced than suggested by the data in the table.

Table 10 also highlights the fact that a number of Swedish firms have dramatically expanded employment in recent decades. Yet even in firms with a very large increase in total employment, this share rarely increased compared to the early 1970s. The Swedish employment share of Electrolux and Securitas is now below 5 percent. Very few firms have remained reasonably intact since the 1970s, which explains why we chose not to include more than eight firms in the table. In fact, only 12 percent of the 252 firms listed on the SSE in 1985 were still listed in 2009 (Fristedt and Sundqvist 2009).

\footnotetext{
${ }^{30}$ Employment in Sweden is admittedly an imperfect indicator of firm size, but it gives a fairly good indication. Selection of the 100 largest firms based on alternative criteria such as sales or value added results in a very similar selection of firms. The measure we use is the only one that exists for all three years.
} 
Table 8 The Aggregate Importance of Firms Listed on the SSE, 1990, 2000 and 2009.

\begin{tabular}{lrrr}
\hline & 1990 & 2000 & 2009 \\
\hline $\begin{array}{l}\text { Number of firms listed on the SSE among the 100 largest } \\
\text { employers in Sweden }\end{array}$ & 48 & 38 & 28 \\
$\begin{array}{l}\text { Number of employees in Sweden of firms listed on the SSE } \\
\text { among the } 100 \text { largest employers in Sweden }\end{array}$ & 435,500 & 357,800 & 230,300 \\
$\begin{array}{l}\text { Share of total Swedish employment in firms listed on the SSE } \\
\text { among the } 100 \text { largest employers in Sweden }\end{array}$ & $9.7 \%$ & $8.6 \%$ & $5.3 \%$ \\
$\begin{array}{l}\text { Employment in Sweden of firms listed on the SSE among the } \\
100 \text { largest employers in Sweden relative to total employment } \\
\text { in Sweden of 100 largest firms }\end{array}$ & $53 \%$ & $46 \%$ & $36 \%$ \\
\hline
\end{tabular}

Note: Size is defined in terms of employment in Sweden.

Source: AKU, Statistics Sweden; National Accounts, Statistics Sweden; Veckans Affärer: 1991 års storföretag; Sveriges största företag 2001/2002; www.largestcompanies.se.

Table 9 Share of Total Employment among 100 Largest Firms in Different Ownership Categories, 1990, 2000 and 2009 (\%).

\begin{tabular}{lrrr}
\hline Ownership category & 1990 & 2000 & 2009 \\
\hline Firms listed on the SSE & 53 & 46 & 36 \\
Private Swedish firms & 7 & 4 & 12 \\
Foreign firms & 5 & 26 & 31 \\
Government-owned firms & 27 & 16 & 16 \\
Cooperatives or foundations & 8 & 8 & 5 \\
Total & 100 & 100 & 100 \\
\hline
\end{tabular}

Source: AKU, Statistics Sweden; National Accounts, Statistics Sweden; Veckans Affärer: 1991 års storföretag; Sveriges största företag 2001/2002; www.largestcompanies.se.

Table 10 Total Number of Employees in Eight Large Swedish Public Firms, 1971, 1990 and 2009.

\begin{tabular}{lrrr}
\hline & 1971 & 1990 & 2009 \\
\hline Atlas Copco & $13,700(3,700)$ & $21,500(4,300)$ & $31,100(3,900)$ \\
Ericsson & $66,900(23,900)$ & $66,100(26,600)$ & $86,400(18,500)$ \\
Sandvik & $18,800(11,000)$ & $25,800(10,300)$ & $47,200(10,900)$ \\
SCA & $12,700(10,200)$ & $31,100(10,700)$ & $49,500(6,600)$ \\
Securitas & $11,000(4,300) \dagger$ & $12,700(6,200)$ & $260,000(10,500)$ \\
H\&M* $_{\text {Electrolux }}$ & $1,100(735)$ & $6,200(2,900)$ & $53,500(4,900)$ \\
Volvo & $31,300(6,200)$ & $150,900(27,600)$ & $50,600(2,400)$ \\
\hline
\end{tabular}

Note: Numbers in parentheses show the number of employees in Sweden. It may be noted that Volvo sold Volvo Automobiles to Ford in 1999, which decreased employment in Volvo by roughly 20,000. All figures have been rounded off to the nearest 100. *Called Erling Persson AB in 1971. +Pertains to 1972; data received directly from Securitas.

Source: Veckans Affärer (1972); Veckans Affärer: 1991 års storföretag; and http://www.largestcompanies.se. 


\section{Concluding Remarks}

Controlling ownership in Sweden has been highly concentrated for a long time. As a consequence, blockholders have generally come to control listed firms. Blockholding itself has been concentrated to a few groups on the Swedish stock market with a long tradition of assuming such a role. This model of corporate governance proved remarkably resilient. We have demonstrated that this no longer holds true.

These old owners are retreating at the same time as it is becoming increasingly difficult to assume or sustain control of firms by means of pyramiding and dual-class shares. This development can be explained to a large extent by the deregulation and globalization of the financial markets starting in the 1980s.

This might look like a vindication of the hypothesis that globalization leads to a world-wide convergence of corporate governance towards the Anglo-American model of dispersed ownership and management control. However, the convergence hypothesis consists of two components: (i) a decline of blockholder control, and (ii) an increasing number of firms in non-Anglo-American countries with dispersed ownership and management control. This study shows that the second component of the convergence hypothesis has failed to materialize in Sweden; management control is not a viable model for corporate governance. Corporate law provides management with few, if any, instruments to establish a leading position vis-à-vis dispersed owners. The law corresponds very well with a corporate culture where management is subordinated to shareholders (Pacces 2007; Nachemson-Ekwall 2010). Further research is needed to establish if these hypotheses hold as explanations to the apparent non-viability of managerial control in Sweden.

We have also demonstrated that the emergence of new wealthy entrepreneurs and investors in connection with the forceful revival of the Swedish stock market around 1980 has broadened the base for the blockholder model in Sweden. Thus, even when stock markets are dominated by capital from institutional investors, very rich industrialists/entrepreneurs are necessary to achieve a wellfunctioning corporate governance of large public firms in Sweden.

Hansmann and Kraakman (2004, p. 35) claim that there is convergence in the sense that an increasing consensus maintains that the "ultimate control over the corporation should be in the hands of the shareholder class", and that other stakeholders (creditors, employees, suppliers and customers) "should have their interests protected by regulatory and contractual means and not through participation in corporate governance." We largely agree with this assertion, but this does not automatically imply convergence towards a particular institutional setup, such as that found in the United States.

Instead of convergence in pertinent institutions and practices, the ownership structure may adjust endogenously. Thus, those forms of ownership best adapted to the new conditions resulting from globalization, deregulation and the largely unchanged institutional setup will expand relative to previously dominant ownership forms. In the Swedish case this has led to a large increase in the share of foreign-owned firms and of ownership through private equity.

Many of the reforms in corporate finance implemented in the European Union are inspired by the U.K. system (Jonnergård and Larsson 2007). Law-makers thus implicitly assume that the Anglo- 
American corporate governance model is ideal and that all countries are converging towards a corporate universe where dispersed ownership and management control predominates. ${ }^{31}$ Prime examples of passed or proposed laws of this kind include outright prohibition of dual-class shares, mandatory bid rules and a minimum number of independent directors. Such laws undermine the basis for blockholder control. If there are strong cultural and/or legal impediments to the emergence of firms with dispersed ownership and management control, such (well-intended) European harmonization measures will instead result in an erosion of stock markets in Europe. Our findings show that such an outcome is underway in Sweden. It is for further research to examine whether and to what extent our findings apply to other European countries.

Thus, although the intellectual arguments for convergence of corporate governance practices towards the Anglo-American model of dispersed ownership and management control are strong, our study of Sweden shows that the case for differentiation between practices in countries is profound when the prevailing market structures, and legal, financial and cultural contexts are recognized. Our study also provides support for the argument that the efficiency of a particular corporate governance model hinges on the complementarity of various constitutive elements (Schmidt and Spindler 2002), and therefore an isolated change in a certain element leads to inconsistencies, making the model less efficient.

We have demonstrated the importance of national corporate law and social norms for the response of corporate governance in Sweden to globalization. When we look for an explanation to the worldwide persistence of the blockholder model of corporate control, our findings could give a clue to where to find an explanation. We are, however, well aware of the fact that this is a case study. The Swedish case is in many ways idiosyncratic. It is a small, highly developed economy with a homogeneous corporate culture. In order to draw more general conclusions regarding the reasons for the failure of the convergence hypothesis to materialize, further research with a much wider geographical scope is required. Since every country is special in some sense it will be difficult to conduct convincing hypothesis testing by means of state-of-the-art econometric techniques. A possible approach might be a combination of statistical testing and in-depth explorations of specific countries similar to the study presented here.

Moreover, our findings indicate that the theoretical arguments for convergence should be qualified. While the theory is convincing when it comes to the effects of globalization on blockholding, the conditions for the viability of management control need to be specified more rigorously. An implicit assumption in the literature seems to be that the retreat of blockholding is a sufficient condition for the emergence of management control in its stead. Our findings demonstrate the importance of specifying the necessary conditions for management control to emerge. Such a development of the theory is an important step on the road to understanding the reasons for the failure of management control to become the dominant world-wide model of corporate control.

\footnotetext{
${ }^{31}$ This is a bit puzzling since despite an enormous research effort it has not been possible to identify an optimal corporate governance system for public firms or to show that any one of the existing systems is superior (Goergen, 2007; Tirole, 2006). This conclusion can also be found in the "varieties of capitalism" literature (Hall and Soskice, 2001).
} 


\section{References}

Agnblad, Jonas, Erik Berglöf, Peter Högfeldt and Helena Svancar (2001), "Ownership and Control in Sweden: Strong Owners, Weak Minorities, and Social Control." In Fabrizio Barca and Marco Becht, eds., The Control of Corporate Europe. Oxford: Oxford University Press, 228-259.

Armour, John, and David A. Skeel, Jr (2007), "Who Writes the Rules for Hostile Takeovers and Why? The Peculiar Divergence of U.S. and U.K. Takeover Regulation." Georgetown Law Journal, Vol. 95, No. 7, 1727-1794.

Barontini, Roberto, and Lorenzo Caprio (2005), "The Effect of Family Control on Firm Value and Performance. Evidence from Continental Europe." European Financial Management, Vol. 12, No. $5,689-723$.

Bebchuk, Lucien Arye, and Mark J. Roe (2004), "A Theory of Path Dependence in Corporate Ownership and Governance." In Jeffrey N. Gordon and Mark J. Roe, eds., Convergence and Persistence in Corporate Governance. Cambridge: Cambridge University Press, 69-113.

Becht, Marco, and J. Bradford DeLong (2005), "Why Has There Been So Little Blockholding in America?" In Randall K. Morck, ed., A History of Corporate Governance Around the World. Chicago and London: University of Chicago Press, 613-660.

Bergh, Andreas, and Gissur Erlingsson (2009), "Liberalization without Retrenchment: Understanding the Consensus on Swedish Welfare State Reforms." Scandinavian Political Studies, Vol. 32, No. 1, 71-94.

Bergström, Clas, and Kristian Rydqvist (1990), "Ownership of Equity in Dual-Class Firms." Journal of Banking and Finance, Vol. 14, No. 2, 255-269.

Berle, Adolph A., and Gardiner C. Means (1932), The Modern Corporation and Private Property. New York: MacMillan.

Bjuggren, Carl Magnus, and Dan Johansson (2008), "Private and Public Employment in Sweden: Is the Prevailing View Misguided?" Mimeo. Stockholm: Ratio.

Bjuggren, Per-Olof, Johan E. Eklund and Daniel Wiberg (2007), “Ownership Structure, Control and Firm Performance: The Effects of Vote-Differentiated Shares." Applied Financial Economics, Vol. 17, No. 16-18, 1323-1334.

Burkart, Mike, and Samuel Lee (2008), "One Share, One Vote: The Theory." Review of Finance, Vol. 12, No. 1, 1-49.

Carlin, Wendy (2010), "Ownership, Corporate Governance, Specialization and Performance: Interpreting Recent Evidence for OECD Countries." In Jean-Philippe Touffut, ed., Does Company Ownership Matter? Efficiency and Growth. Cheltenham, U.K. and Northampton, MA: Edward Elgar.

Carlsson, Rolf H. (2007), "Swedish Corporate Governance and Value Creation: Owners still in the Driver's Seat." Corporate Governance: An International Review, Vol. 15, No. 6, 1038-1055.

Collin, Sven-Olof (1995), "The Institutional Control of the Corporation - Extending the Debate on the Separation of Ownership from Control." Corporate Governance: An International Review, Vol. 3, No. 3, 118-127.

Cronqvist, Henrik, and Mattias Nilsson (2003), "Agency Costs of Controlling Minority Shareholders." Journal of Financial and Quantitative Analysis, Vol. 38, No. 4, 695-719.

Denis, Diane K., and John J. McConnell (2003), "International Corporate Governance." Journal of Financial and Quantitative Analysis, Vol. 27, No. 1, 1-35.

Drucker, Peter F. (1976), The Unseen Revolution: When Pension Fund Socialism Came to America. New York: Harper \& Row.

Fristedt, Daniel, and Sven-Ivan Sundqvist (2006, 2007, 2008, 2009), Ägarna och Makten i Sveriges Börsföretag/Owners and Power in Sweden's Listed Companies 2006/2007/2008/2009.

Stockholm: SIS Ägarservice. 
Fristedt, Daniel, and Sven-Ivan Sundqvist (2010), Styrelser och Revisorer i Sveriges Börsföretag 20092010/Boards and Auditors in Sweden's Listed Companies 2009-2010. Stockholm: SIS Ägarservice.

Giannetti, Mariassunta, and Andrei Simonov (2006), "Which Investors Fear Expropriation? Evidence from Investors' Portfolio Choices." Journal of Finance, Vol. 61, No. 3, 1507-1547.

Gilson, Ronald J. (2006), "Controlling Shareholders and Corporate Governance: Complicating the Comparative Taxonomy." Harvard Law Review, Vol. 119, No. 6, 1641-1679.

Glete, Jan (1994), Nätverk i näringslivet. Stockholm: SNS Förlag.

Goergen, Marc (2007), "What Do We Know about Different Systems of Corporate Governance?" Working Paper No. 167, European Corporate Governance Institute, Brussels.

Gourevitch, Peter Alexis, and James J. Shinn (2005), Political Power and Corporate Control: The New Global Politics of Corporate Governance. Princeton, NJ: Princeton University Press.

Hall, Peter, and David Soskice, eds. (2001), Varieties of Capitalism: The Institutional Foundations of Comparative Advantage. Oxford: Oxford University Press.

Hansmann, Henry, and Reinier Kraakman (2004), "The End of History for Corporate Law." In Jeffrey N. Gordon and Mark J. Roe, eds., Convergence and Persistence in Corporate Governance. Cambridge: Cambridge University Press, 33-68.

Henrekson, Magnus, and Ulf Jakobsson (2001), "Where Schumpeter Was Nearly Right - the Swedish Model and Capitalism, Socialism and Democracy." Journal of Evolutionary Economics, Vol. 11, No. 3, 331-358.

Henrekson, Magnus, and Ulf Jakobsson (2003), "The Transformation of Ownership Policy and Structure in Sweden: Convergence towards the Anglo-Saxon Model?" New Political Economy, Vol. 8, No. 1, 73-102.

Henrekson, Magnus, and Ulf Jakobsson (2005), "The Swedish Model of Ownership and Corporate Control in Transition." In Harry Huizinga and Lars Jonung, eds., Who Will Own Europe? The Internationalisation of Asset Ownership in Europe. Cambridge: Cambridge University Press, 207246.

Henrekson, Magnus, and Nina Öhrn (2011),"Fortsätter huvudkontoren att flytta ut?" Ekonomisk Debatt, Vol. 39, No. 1, 29-38.

Hill, Jennifer G. (2010), "The Rising Tension between Shareholder and Director Power in the Common Law World." Corporate Governance, Vol. 18, No. 4, 344-359.

Högfeldt, Peter (2005), "The History and Politics of Corporate Ownership in Sweden." In Randall K. Morck, ed., A History of Corporate Governance around the World: Family Business Groups to Professional Managers. Chicago and London: University of Chicago Press, 517-580.

Holmén, Martin (2011), "Foreign Investors and Dual Class Shares." Paper presented at the Nordic Corporate Governance Forum Conference, Helsinki, May 5-6.

Holmén, Martin, and Peter Högfeldt (2005a), "Pyramidal Discounts: Tunnelling or Agency Costs?" Working Paper No. 73, European Corporate Governance Institute, Brussels.

Holmén, Martin, and Peter Högfeldt (2005b), "A Law and Finance Analysis of Initial Public Offerings." Journal of Financial Intermediation, Vol. 13, No. 2, 324-358.

Holmén, Martin, and John D. Knopf (2004), "Minority Shareholder Protections and the Private Benefits of Control for Swedish Mergers." Journal of Financial and Quantitative Analysis, Vol. 39, No. 1, 167-191.

Holmén, Martin, and Eugene Nivorozhkin (2007), "The Impact of Family Ownership and Dual Class Shares on Takeover Risk." Applied Financial Economics, Vol. 17, No. 10, 785-804.

Holmén, Martin, and Eugene Nivorozhkin (2008), "Tender Offers versus Block Trades: Empirical Evidence." Mimeo. Department of Economics, University of Uppsala.

Isaksson, Anders (1999), Effekter av venture capital i Sverige. NUTEK B 1999:3. Stockholm: Nutek Förlag. 
Isaksson, Mats, and Rolf Skog (1994), "Corporate Governance in Swedish Listed Companies." In Theodor Baums, Richard M. Buxbaum and Klaus J. Hopt, eds., Institutional Investors and Corporate Governance. Berlin and New York: Walter de Gruyter.

Jackson, Gregory, and Hideaki Miyajima (2007), "Varieties of Capitalism, Varieties of Markets: Mergers and Acquisitions in Japan, Germany, France, the UK and USA." RIETI Discussion Paper No. 07054. Tokyo: Research Institute of Economy, Trade and Industry.

Jansson, Per-Ola (2008), Svenska Fondhandareföreningen etthundra år 1908-2008. Stockholm: Swedish Securities Dealers' Association.

Jensen, Michael C. (2007), "The Economic Case for Private Equity (and Some Concerns) - pdf of Keynote Slides." Harvard NOM Research Paper No. 07-02. Cambridge, MA: Harvard Business School.

Johansson, Anders L., and Lars Magnusson (1998), LO andra halvseklet. Fackföreningsrörelsen och samhället. Stockholm: Atlas.

Jonnergård, Karin, and Ulf Larsson (2007), "Conceptions of Ownership Structures and the Unresponsive Regulation: The Case of Swedish Corporate Governance Reform." Mimeo. Linnaeus University, Växjö, Sweden.

Jonung, Lars (1994), "The Rise and Fall of Credit Controls: The Case of Sweden, 1939-89." In Michael D. Bordo and Forest Capie, eds., Monetary Regimes in Transition. Cambridge: Cambridge University Press, 346-370.

Kallifatides, Markus, Sophie Nachemson-Ekwall and Sven-Erik Sjöstrand (2010), Corporate Governance in Modern Financial Capitalism: Old Mutual's Hostile Takeover of Skandia. Cheltenham, U.K. and Northampton, MA: Edward Elgar.

Kaplan, Steven N., and Per Strömberg (2009), "Leveraged Buyouts and Private Equity." Journal of Economic Perspectives, Vol. 23, No. 1, 121-146.

Karlsson, Arne, and Ulf Myrberg (1985), Investmentbolagsrabatten - ett värderingsfenomen? Stockholm: Ekonomiska forskningsinstitutet vid Handelshögskolan i Stockholm.

Katzenstein, Peter (1985), Small States in World Markets. Ithaca, NY: Cornell University Press.

Korpi, Walter (1982), "The Historical Compromise and Its Dissolution." In Bengt Rydén and Villy Bergström, eds., Sweden: Choices for Economic and Social Policy in the 1980s. London: George Allen \& Unwin, 130-140.

La Porta, Rafael, Florencio Lopez-de-Silanes and Andrei Shleifer (1999), "Corporate Ownership around the World." Journal of Finance, Vol. 54, No. 3, 471-517.

Lindbeck, Assar (1997), "The Swedish Experiment." Journal of Economic Literature, Vol. 35, No. 3, 1273-1319.

Lindgren, Gunnar (1953), "Shareholders and Shareholder Participation in the Larger Companies' Meetings in Sweden." Weltwirtschaftliches Archiv, Vol. 71, No. 2, 281-298.

Lindgren, Håkan (1994a), "The Comparative Advantages of Business Groups: Some Swedish Evidence." In Margit Dritsas and Terry Gourvish, eds., European Enterprise: Strategies of Adaptation and Renewal in the Twentieth Century. Aten: Trochalia Publications.

Lindgren Håkan (1994b), Aktivt ägande. Investor under växlande konjunkturer. Stockholm: Institutet för ekonomisk-historisk forskning (EHF).

Meidner, Rudolf (1978), Employee Investment Funds. An Approach to Collective Capital Formation. London: George Allen \& Unwin.

Morck, Randall K., ed. (2005), A History of Corporate Governance around the World. Family Business Groups and Professional Managers. Chicago and London: University of Chicago Press.

Morck, Randall K., Daniel Wolfenzon och Bernard Yeung (2005), "Corporate Governance, Economic Entrenchment, and Growth". Journal of Economic Literature, Vol. 43, No. 3, 655-720. 
Nachemson-Ekwall, Sophie (2010), "Corporate Governance in Financial Capitalism. Regulatory Arbitrage in Swedish Cross-Boarder Hostile Takeovers During the Sixth Takeover Wave - What Can We Learn?". Mimeo, Department of Management and Organization, Stockholm School of Economics.

Nutek and Swedish Venture Capital Association (2003), Utvecklingen för riskkapitalbolagens portföljbolag. R 2003:11. Stockholm: Nutek Förlag.

Öberg, PerOla, and Torsten Svensson, eds. (2005), Power and Institutions in Industrial Relation Regimes: Political Science Perspectives on the Transition of the Swedish Model. Stockholm: National Institute of Working Life.

Ohlsson, Lennart (2006), Best Practice Venture Capital. Stockholm: KTH Centre for Banking and Finance, Royal Institute of Technlogy.

Pacces, Alessio M. (2007), Featuring Control Power - Corporate Law and Economics Revisited. Rotterdam: Rotterdam Institute of Law and Economics, Erasmus University.

Petersson, Tom (2001), "Promoting Entrepreneurship. Bank-Connected Investment Development Companies in Sweden 1962-1990." In Magnus Henrekson, Mats Larsson and Hans Sjögren, eds., Entrepreneurship in Business and Research. Essays in Honour of Håkan Lindgren. Stockholm: Probus Förlag and Institutet för ekonomisk-historisk forskning, 113-135.

Pontusson, Jonas (1992), The Limits of Social Democracy. Investment Politics in Sweden. Ithaca, NY: Cornell University Press.

Rajan, Raguram, and Luigi Zingales (2001), "The Influence of Financial Revolution on the Nature of Firms." American Economic Review, Vol. 91, No. 2, 206-211.

Rajan, Raguram, and Luigi Zingales (2003), "The Great Reversals: The Politics of Financial Development in the Twentieth Century." Journal of Financial Economics, Vol. 69, No. 1, 5-50.

Reiter, Joakim (2003), “Changing the Microfoundations of Corporatism: The Impact of Financial Globalisation on Swedish Corporate Ownership?" New Political Economy, Vol. 8, No. 1, 103-126.

Roe, Mark J. (2003), Political Determinants of Corporate Governance. Oxford: Oxford University Press.

Roe, Mark J. (2004), "Modern Politics and Ownership Separation." In Jeffrey N. Gordon and Mark J. Roe, eds., Convergence and Persistence in Corporate Governance. Cambridge: Cambridge University Press, 252-290.

Roine, Jesper, and Daniel Waldenström (2009), "Wealth Concentration over the Path of Development: Sweden, 1873-2006." Scandinavian Journal of Economics, Vol. 111, No. 1, 151187.

Roine, Jesper, and Daniel Waldenström (2011), "On the Role of Capital Gains in Top Incomes." IFN Working Paper No. 870. Stockholm: Research Institute of Industrial Economics.

Schmidt, Reinhard H., and Gerald Spindler (2002), "Path Dependence, Corporate Governance and Complementarity." International Finance, Vol. 5, No. 3, 311-333.

Shleifer, Andrei (2000), Inefficient Markets: An Introduction to Behavioral Finance. Oxford and New York: Oxford University Press.

SOU 1967:7, Ägande och inflytande inom det privata näringslivet. Koncentrationsutredningen. Stockholm: Allmänna Förlaget.

SOU 1968:59, Förenklad aktiehantering: nya regler för aktiebrev och aktiebok. Betänkande av Fondbörsutredningen. Stockholm: Statens offentliga utredningar.

Spånt, Roland (1975), Förmögenhetsfördelningen i Sverige. Stockholm: Prisma.

Stafsudd, Anna (2009), "Corporate Networks and Informal Governance Mechanisms: A Small Worlds Approach to Sweden." Corporate Governance: An International Review, Vol. 17, No. 1, 62-76.

Steinmo, Sven (2003), "Bucking the Trend? Social Democracy in a Global Economy: The Swedish Case Up Close." New Political Economy, Vol. 8, No. 1, 31-48. 
Strandell, Ann-Christine (2000), "Utlandsägda företag." In Svenskt näringsliv och näringspolitik 2000. Stockholm: NUTEK Förlag.

Sundin, Anneli, and Sven-Ivan Sundqvist (1994, 1999), Ägarna och Makten i Sveriges Börsföretag/Owners and Power in Sweden's Listed Companies 1994/1999. Stockholm: Dagens Nyheters Förlag.

Sundqvist, Sven-Ivan (1989), Ägarna och Makten i Sveriges Börsföretag/Owners and Power in Sweden's Listed Companies 1989. Stockholm: Dagens Nyheters Förlag.

Sveriges största företag 2001/2002 (2003). Bromma: Ekonomisk Litteratur.

Swedish Agency for Growth Policy Analysis (2010), "Foreign Controlled Enterprises 2009." Statistik 2010:04. Stockholm and Östersund: Tillväxtanalys.

Tåg, Joacim (2011), "The Real Effects of Private Equity Buyouts." In Douglas Cumming, ed., The Oxford Handbook of Private Equity. Oxford: Oxford University Press.

Tirole, Jean (2006), The Theory of Corporate Finance. Princeton, NJ: Princeton University Press.

U.K. Takeover Panel (2010), "Review of Certain Aspects of the Regulation of Takeover Bids." October 22, 2010. Available online (10-11-30): http://www.thetakeoverpanel.org.uk/.

UNCTAD (various years), World Investment Report. New York: United Nations.

Veckans Affärer (1972), Sveriges 1000 största företag. Stockholm: Specialtidningsförlaget.

Veckans Affärer (1991), Sveriges 500 största företag. Bromma: Ekonomisk Litteratur.

Waldenström, Daniel (2002), "Why Are Securities Transactions Taxed? Evidence from Sweden, 19091991." Financial History Review, Vol. 9, No. 2, 164-191.

Waldenström, Daniel (2010), "Welfare State Billionaires." Mimeo. Stockholm: Research Institute of Industrial Economics.

Weild, David, and Edward Kim (2009), A Wake-up Call for America. The Capital Market Series. Grant Thornton, November. 
Figure 1 Discount on the share price of Investor AB (1930-2010) and Industrivärden (1993-2010) relative to the net asset value (\%).

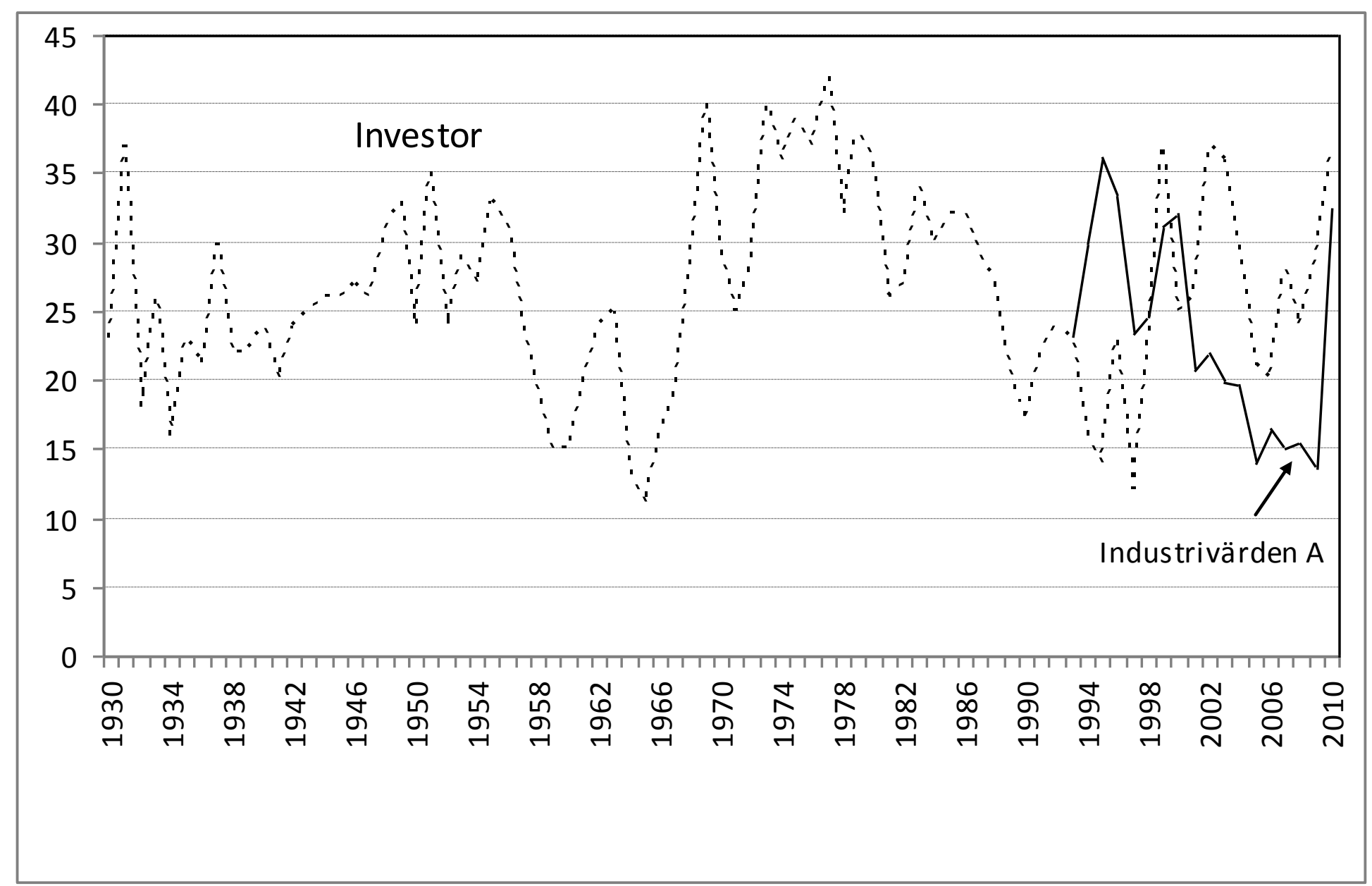


Figure 2 Stock Market Capitalization as a Share of GDP, Sweden 1908-2010.

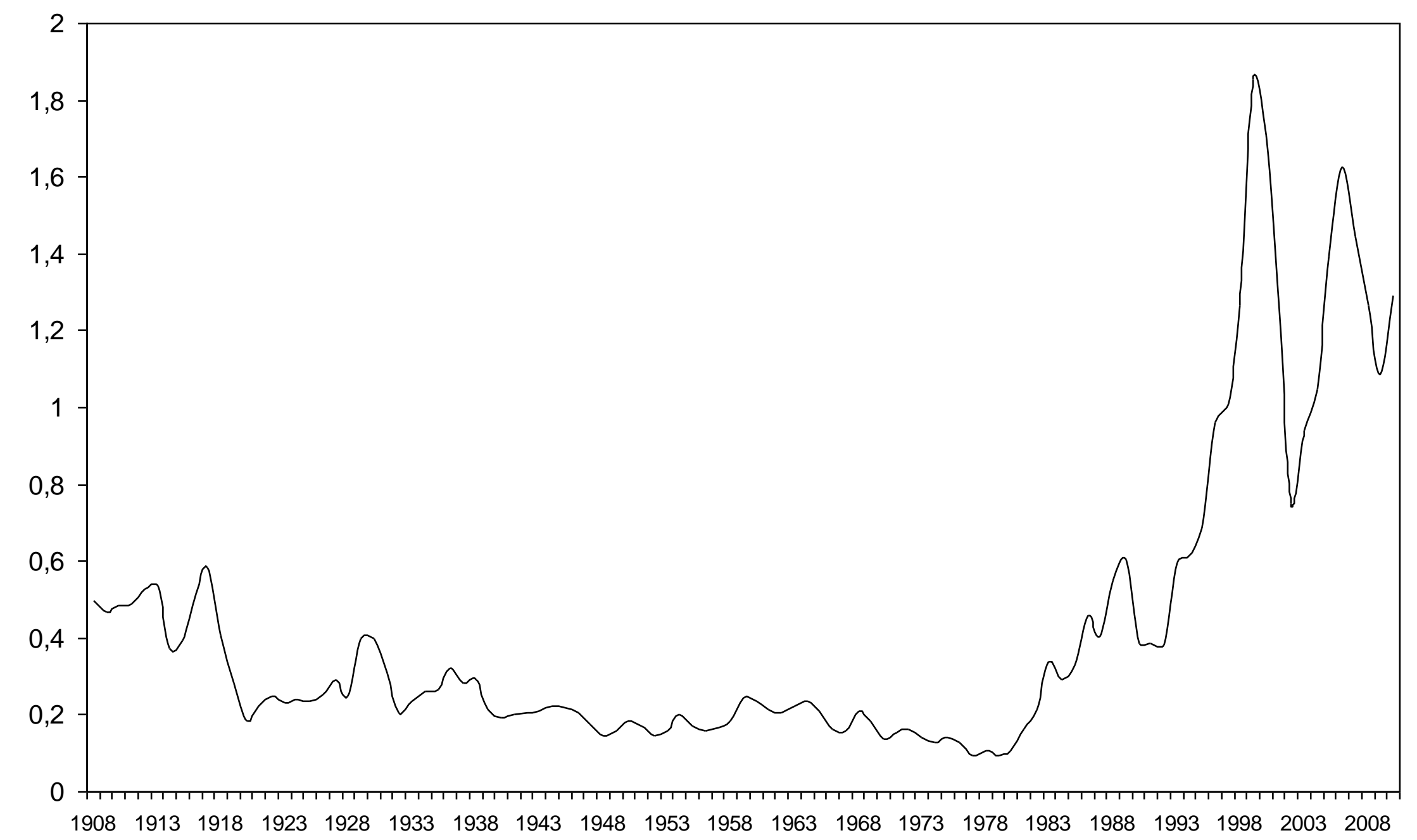


Figure 3 Ratio of Top Percentile Income Share with and without Capital Gains in Selected Countries, 1980-2006.

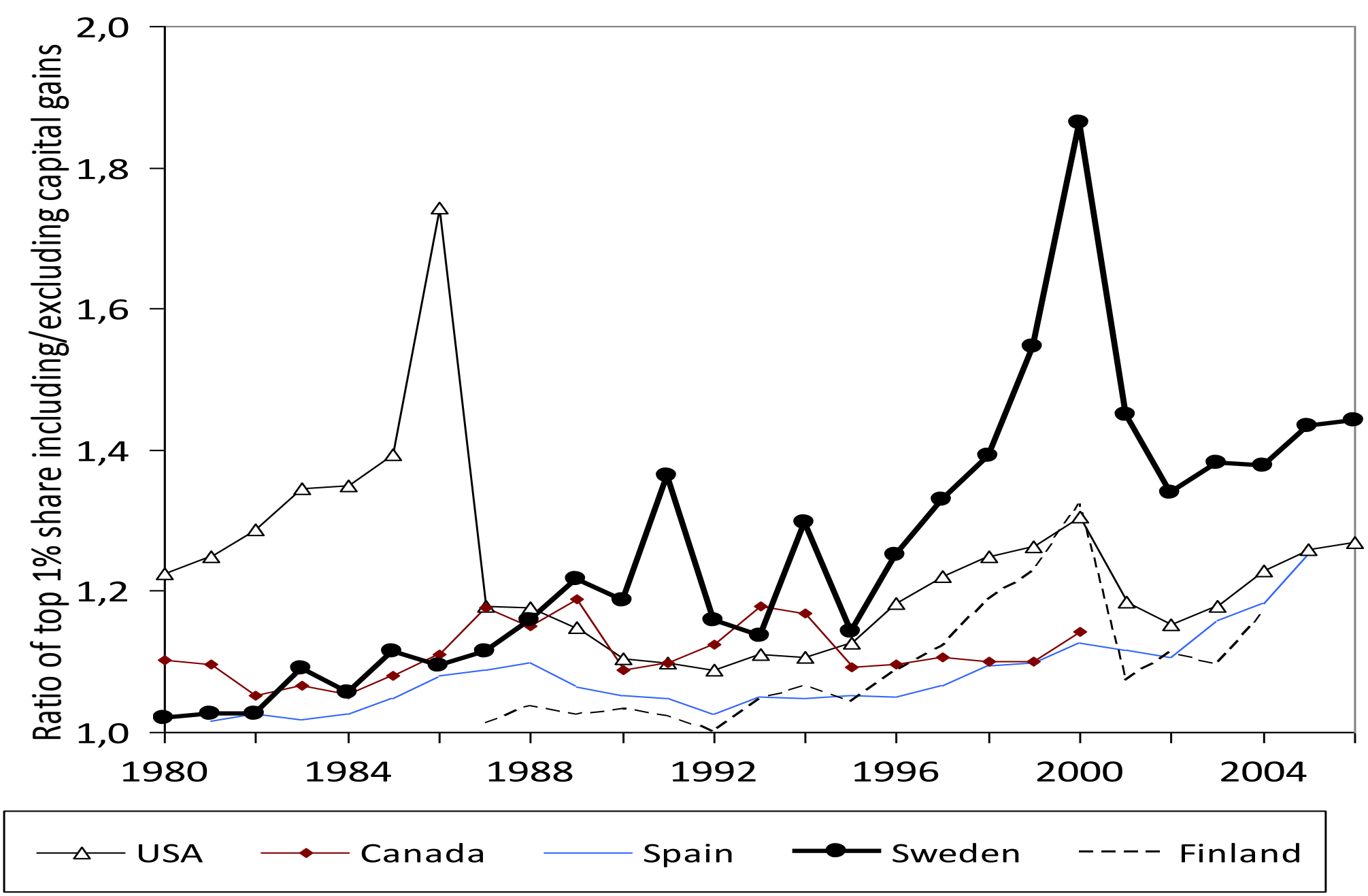


Figure 4 Financial Household Savings as Share of Disposable Income in Sweden, 1995-2009 (percent)

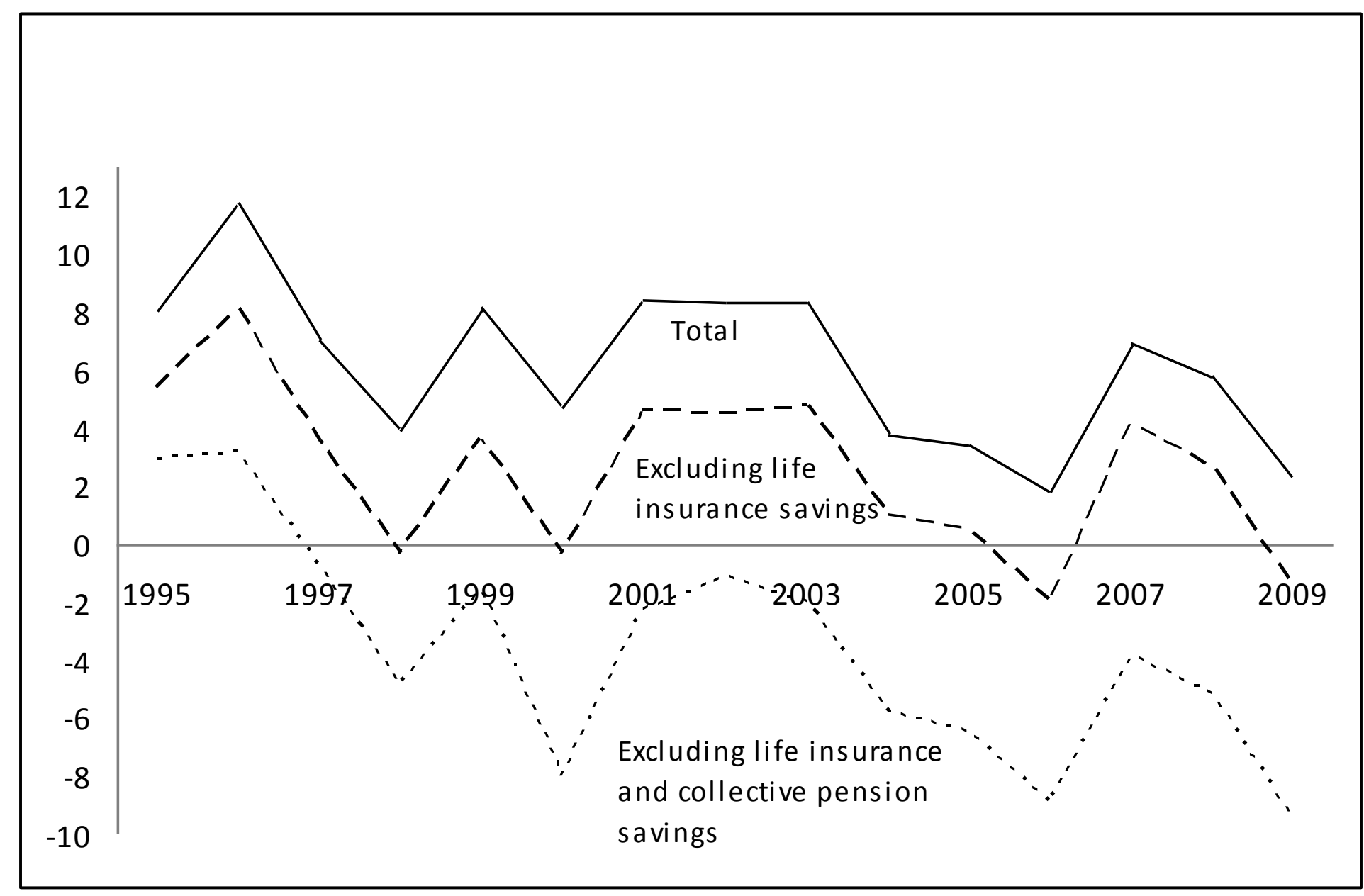

Source: Statistics Sweden. 
Figure 5 The Stock of Inward FDI as a Share of GDP in Sweden and the OECD, 1980-2009 (\%).

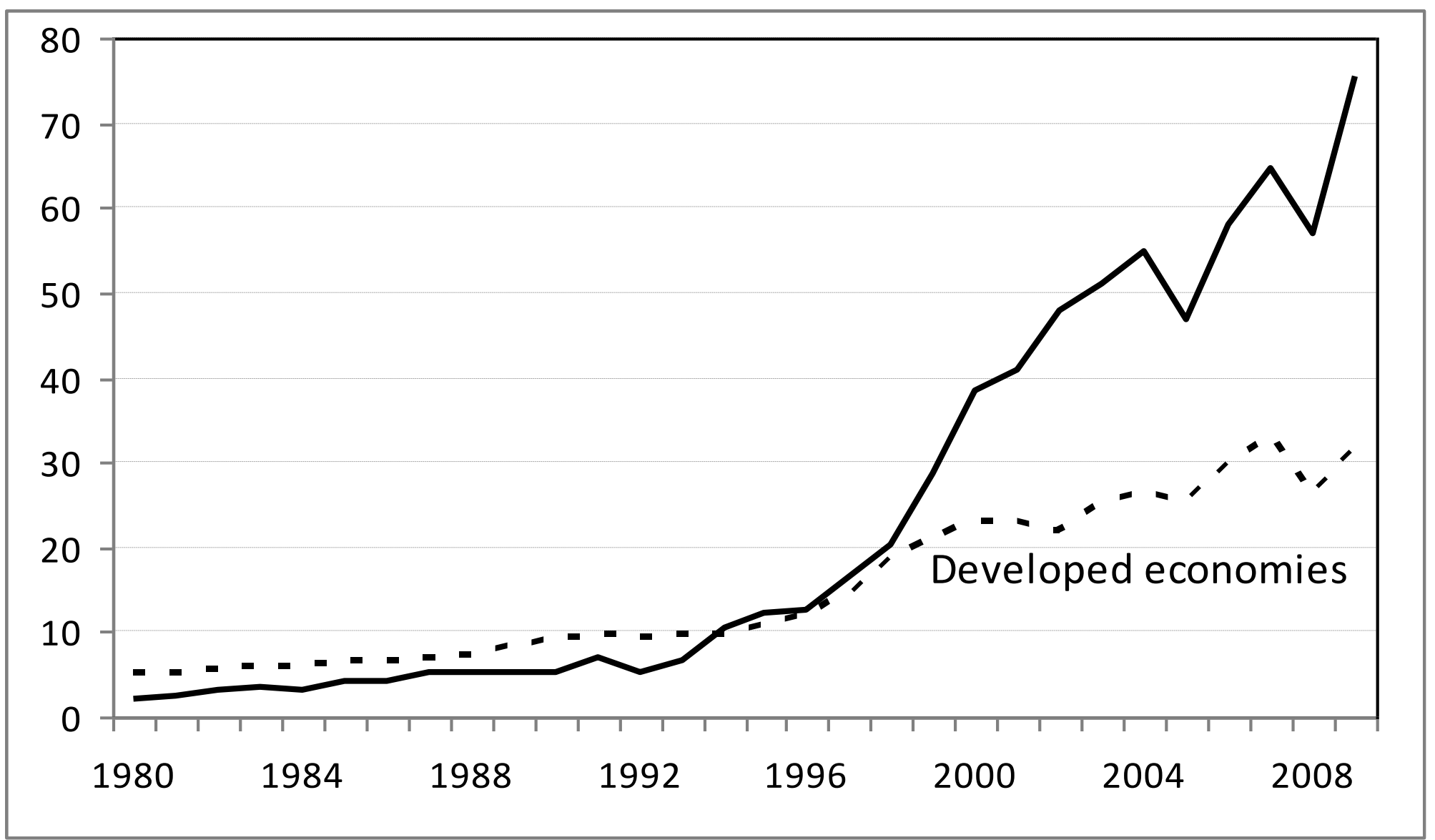


Figure 6 Employees in Foreign-owned Firms in Sweden and their Share of All Employees in the Swedish Private Sector, 1980-2009 (percent).

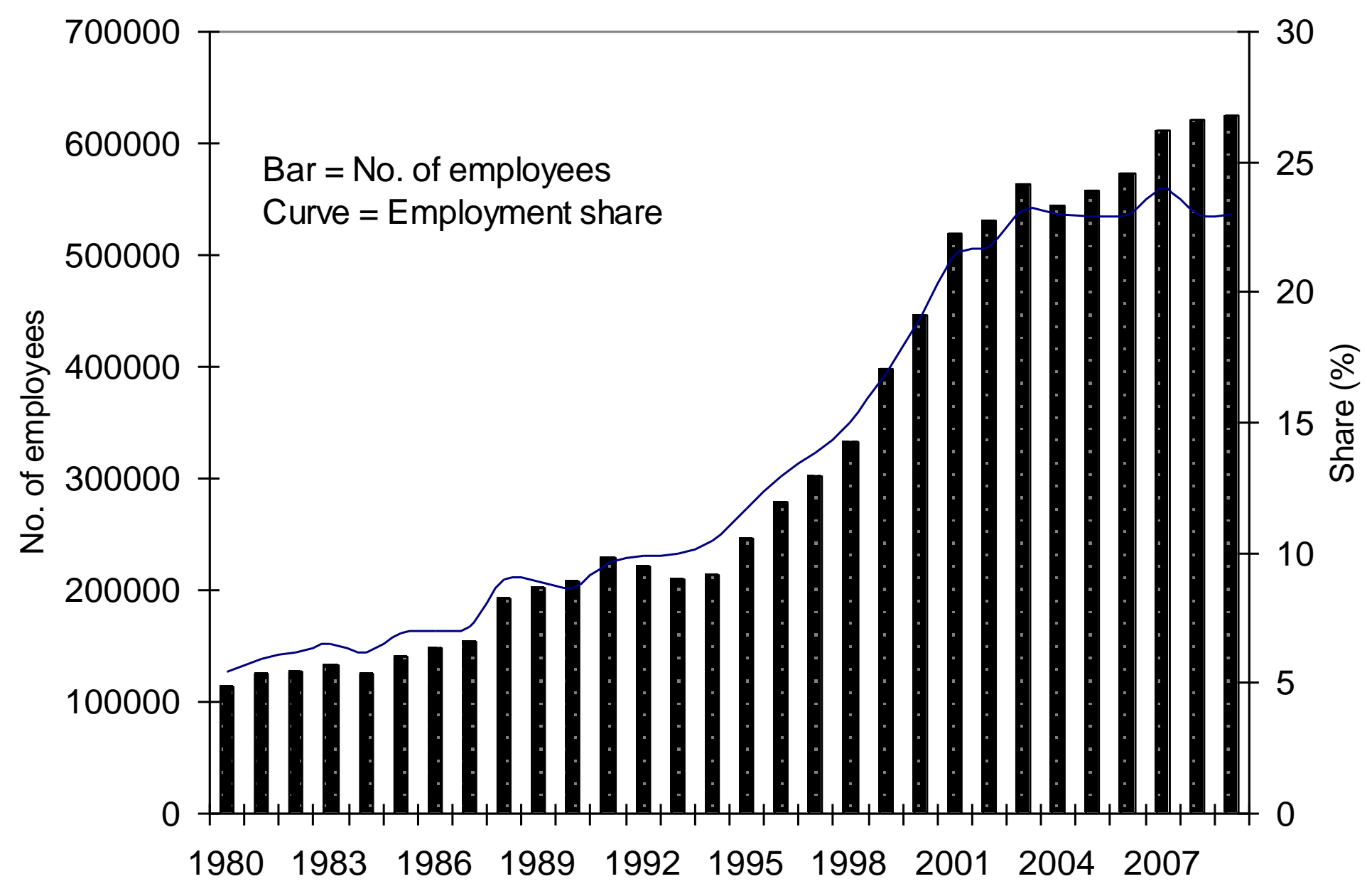


Figure 7 Real Market Cap as a Share of Real GDP in Sweden and the U.K., 1979-2009.

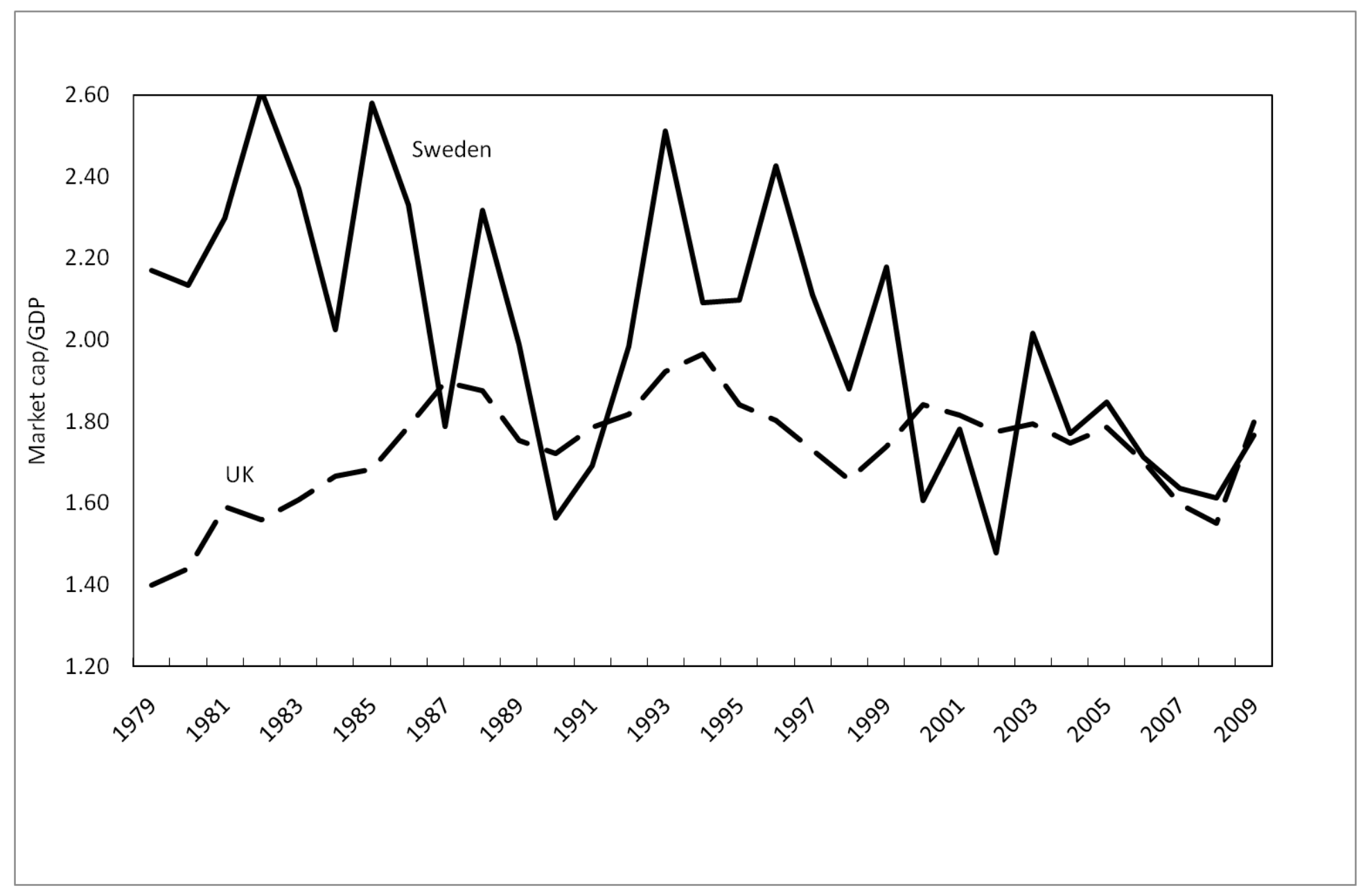

